\title{
Diminishing Arctic Sea Ice Promotes Stronger Surface Winds ${ }^{\mathscr{O}}$
}

\author{
JOHN MIODUSZEWSKI AND STEPHEN VAVRUS \\ Nelson Institute Center for Climatic Research, University of Wisconsin-Madison, Madison, Wisconsin \\ MUYIN WANG \\ Joint Institute for the Study of the Atmosphere and Oceans, University of Washington, and \\ Pacific Marine Environmental Laboratory, National Oceanic and Atmospheric Administration, Seattle, Washington
}

(Manuscript received 2 March 2018, in final form 20 May 2018)

\begin{abstract}
Projections of Arctic sea ice through the end of the twenty-first century indicate the likelihood of a strong reduction in ice area and thickness in all seasons, leading to a substantial thermodynamic influence on the overlying atmosphere. This is likely to have an effect on winds over the Arctic basin because of changes in atmospheric stability, surface roughness, and/or baroclinicity. Here we identify patterns of wind changes in all seasons across the Arctic and their likely causal mechanisms, particularly those associated with sea ice loss. Output from the Community Earth System Model Large Ensemble Project (CESM-LE) was analyzed for the recent past (primarily 1971-2000) and future (2071-2100). Mean near-surface wind speeds over the Arctic Ocean are projected to increase by late century in all seasons but especially during autumn and winter, when they strengthen by up to $50 \%$ locally. The most extreme wind speeds in the 95 th percentile change even more, increasing in frequency by up to $100 \%$. The strengthened winds are closely linked to decreasing surface roughness and lower-tropospheric stability resulting from the loss of sea ice cover and consequent surface warming (exceeding $20^{\circ} \mathrm{C}$ warmer in the central Arctic in autumn and winter), as well as local changes in the storm track. The implications of stronger future winds include increased coastal and navigational hazards. Our findings suggest that increasing winds, along with reduction of sea ice, rising sea level, and thawing permafrost, represent another important contributor to the growing problem of Arctic coastal erosion.
\end{abstract}

\section{Introduction}

The Arctic's pronounced sea ice loss has become a defining feature of Arctic climate change and plays a leading role in the observed amplified Arctic surface warming in recent decades (e.g., Serreze et al. 2007; Comiso et al. 2017; Screen and Simmonds 2010; Stroeve et al. 2012a). Since 1979, Arctic sea ice extent has declined by more than $40 \%$ during summer (e.g., Stroeve et al. 2012a; Cavalieri and Parkinson 2012; Serreze and Stroeve 2015; Onarheim et al. 2018), including a greater composition of younger (Nghiem et al. 2007; Maslanik et al. 2007, 2011) and thinner (Kwok and Rothrock 2009;

Supplemental information related to this paper is available at the Journals Online website: https://doi.org/10.1175/JCLID-18-0109.s1.

Corresponding author: John Mioduszewski, jmioduszewsk@ wisc.edu
Kwok et al. 2009; Lindsay and Schweiger 2015) ice. The negative trends in sea ice are likely a result of decadalscale variability and rising temperatures from increases in atmospheric greenhouse gases (Notz and Marotzke 2012; Stroeve and Notz 2015). Evaluation of model output from climate models used in phase 5 of the Coupled Model Intercomparison Project (CMIP5) predict that the summer Arctic will become ice free within a few decades because of the increased greenhouse gas forcing (e.g., Stroeve et al. 2012b; Wang and Overland 2012; Massonnet et al. 2012).

Sea ice plays a central role in the local climate system through its influence on surface albedo, heat and moisture fluxes between the atmosphere and ocean, surface friction, and ocean circulation. The effect of sea ice loss on the atmosphere has now been documented in numerous studies [see Vihma (2014) and references therein]. It has been well established through modeling experiments and observational evidence that sea ice loss results in increased turbulent heat flux into the 
atmosphere, leading to increased tropospheric moisture, precipitation and cloud cover, increased surface temperature, and decreased static stability, especially in autumn and winter (Deser et al. 2010; Rinke et al. 2006; Serreze et al. 2009; Francis et al. 2009; Overland and Wang 2010; Screen and Simmonds 2010; Screen et al. 2013). Following this chain of processes, a robust lowering of SLP is collocated with sea ice and turbulent flux anomalies, particularly in winter (Screen et al. 2014; Gervais et al. 2016; Cassano et al. 2014), potentially leading to increased baroclinic instability and cyclogenesis (Warshaw and Rapp 1973; Royer et al. 1990; Jaiser et al. 2012).

Whether a local lowering of SLP translates into more frequent or intense cyclones is a matter of considerable debate. Numerous studies have found a significant increase in frequency and intensity of cyclones entering the Arctic from midlatitudes during the latter half of the twentieth century (Zhang et al. 2004; Trigo 2006; Sorteberg and Walsh 2008; Sepp and Jaagus 2011). This may be associated with a poleward shift in storm tracks due to a corresponding shift in baroclinic instability zones (Yin 2005; McDonald 2011). However, many others have reported a decrease or no change in strength or frequency of these cyclones (Murray and Simmonds 1995; Sinclair and Watterson 1999; Bengtsson et al. 2006; Watterson 2006; Day et al. 2018), though results are subject to the season of analysis and tracking method used (e.g., Zolina and Gulev 2002; Koyama et al. 2017). The Aleutian low (AL) in particular is generally projected to deepen in a warming climate, but there is no consensus on the cause(s). The primary potential mechanisms include the aforementioned lowering of local SLP due to warming of surface air via enhanced turbulent heat fluxes (Gervais et al. 2016; Gan et al. 2017) and greenhouse gas forcing (Boer et al. 2000; Salathé 2006). Moreover, McCusker et al. (2017) found that both combine to amplify the strengthening of the AL while amplifying the response at upper levels.

The climatology of Arctic winds was reviewed in Hughes and Cassano (2015), who make the point that they are integral to the process of heat transfer between atmosphere and ocean. This process is especially important at the ice edge where local-scale adjustments in SLP take place as a result (Seo and Yang 2013), and Zhang et al. (2018) found stronger winds at the ice edge resulting from this enhanced baroclinicity in their study of the Beaufort and Chukchi Seas. In these two rapidly changing regions, Stegall and Zhang (2012) found a trend of increasing monthly mean and 95 th percentile July-November wind speeds, likely resulting from retreating sea ice and the corresponding shift in the Aleutian low and Beaufort high in these seasons. There have also been some increases noted in wind and associated waves elsewhere across the ice-free Arctic and high latitudes in recent decades (Young et al. 2012; Overeem et al. 2011; Spreen et al. 2011; Wang et al. 2015), with increased wave heights due to additional factors such as a longer open water season and less landfast ice (Overeem et al. 2011; Francis et al. 2011; Stopa et al. 2016; Waseda et al. 2018).

In contrast to the body of research on cyclones and SLP, relatively few studies have focused on the projected changes in basinwide Arctic wind speeds, even though they strongly affect sea ice distribution, navigation, and coastal erosion. Future projections of Arctic wind speed and wave heights to the end of the twentyfirst century were performed by Khon et al. (2014) and Dobrynin et al. (2012), who reported significant increases in autumn that were largest in locations of greatest ice retreat, where a longer fetch can more than double the wave-height response. McInnes et al. (2011) and Aksenov et al. (2017) reported significantly increased winds by the end of the century in parts of the Arctic, but also did not investigate potential causes. In contrast, Knippertz et al. (2000) attributed projected winter wind increases on the Atlantic side of the Arctic to changes in the boundary layer responding to ice cover, identifying static stability and surface roughness changes as primary factors. Seo and Yang (2013) similarly investigated the influence of sea ice concentration on the Arctic boundary layer and found that reduced ice coverage reduces atmospheric stability, increasing surface winds. Seasons with the greatest air-sea temperature contrast generated the strongest change in boundary layer temperature and stability, and, consequently, wind speed (Seo and Yang 2013).

Previous work has thus identified increased future wind speeds over the Arctic in certain seasons and locations, but no comprehensive analysis or diagnosis over the entire basin for the whole year has been conducted. The present study seeks to provide a more comprehensive analysis of projected future Arctic surface winds by building on past projections of Arctic change, considering the range of scenarios within the internal variability of the climate system as projected by the Community Earth System Model's (CESM) high-emissions scenario. We hypothesize that increased temperature and turbulent fluxes occur in areas where ice loss is greatest and are associated with lowered sea level pressure, reduced surface roughness, and decreased static stability, all of which favor stronger surface winds.

\section{Data}

Our current study is solely based on outputs from the CESM Large Ensemble Project (CESM-LE; Kay et al. 
TABLE 1. Description of the variables and time periods used in this study. Levels of the model atmosphere are counted from the bottom up.

\begin{tabular}{llll}
\hline \hline \multicolumn{1}{c}{ Variable } & \multicolumn{1}{c}{ Height } & Frequency & Time periods \\
\hline Sea ice concentration & Surface & Monthly mean & $1971-2000,2071-2100$ \\
Air temperature & Lowest level & Monthly mean & $1971-2000,2071-2100$ \\
Sea level pressure & Surface & Monthly mean & $1971-2000,2071-2100$ \\
Turbulent heat fluxes & Surface & Monthly mean & $1971-2000,2071-2100$ \\
Surface wind speed & $10 \mathrm{~m}$ & Monthly mean & $1971-2000,2071-2100$ \\
Wind speed aloft & Fourth level & Monthly mean & $1971-2000,2071-2100$ \\
Wind speed aloft & Seventh level & Monthly mean & $1971-2000,2071-2100$ \\
Zonal wind speed & Lowest level & 6h instantaneous & $1991-2000,2071-80$ \\
Meridional wind speed & Lowest level & 6h instantaneous & $1991-2000,2071-80$ \\
\hline
\end{tabular}

2015). The CESM is a fully coupled global climate model with atmospheric, oceanic, terrestrial, and sea ice components (Hurrell et al. 2013). The CESM-LE was designed to enable an assessment of projected change in the climate system while incorporating a wide range of internal climate variability (Kay et al. 2015). It consists of 40 ensemble members simulating the period 19202100 under historical and external (RCP8.5 emissions scenario) radiative forcing. Internal variability is assessed using the spread generated by the small, random round-off level difference (order $10^{-14} \mathrm{~K}$ ) in the initial air temperature field that is initially applied to each ensemble member. The model has been widely used for studies of past, present, and future climate (e.g., Gervais et al. 2016; Peings et al. 2017). The CESM's present-day climatology is one of the most realistic among global models in the CMIP5 collection (Knutti et al. 2013). Its sea ice coverage compares favorably with satellite observations (Jahn et al. 2016), though there is substantial spread in the CESM-LE interensemble ice area (Swart et al. 2015; Jahn et al. 2016) and thickness (Labe et al. 2018). In fact, Rosenblum and Eisenman (2017) found that CESM-LE ensemble members that simulated present day Arctic sea ice most accurately also exhibited the strongest warm bias, though for our purposes it is the sensitivity of the atmosphere to ice cover that is most important within the constraints of internal variability.

Model output was obtained for the periods 1971-2000 and 2071-2100 to facilitate comparison between a present-day climate and that of the end of the twentyfirst century, though the present trend in sea ice loss has accelerated since 2000. Variables include sea ice concentration, air temperature at the lowest model level, SLP, turbulent heat fluxes, and wind speed near the surface $(10 \mathrm{~m})$ and aloft (Table 1). The lowest atmospheric level in the model's hybrid-sigma vertical coordinate system has a pressure 0.9925 as large as the surface pressure at a grid point. This level is around $60 \mathrm{~m}$ above the surface, based on the hypsometric equation for typical Arctic temperatures. Because of the restricted availability of 6-hourly data in the CESM-LE as well as its instantaneous resolution, all wind data at levels other than $10 \mathrm{~m}$ are limited to the periods 19912000 and 2071-80. We choose surface wind speed (at $10 \mathrm{~m}$ ) as our primary analysis metric because it has more societal relevance to Arctic climate change and has a more straightforward interpretation than winds at the 0.9925 hybrid-sigma level.

Statistical significance for analysis of change between the two time periods is calculated using the intraensemble standard deviation for a given variable at each grid cell, with significance indicated when the change exceeds 1 standard deviation. This method has been employed for the CESM-LE previously (Vavrus et al. 2017) and has the advantage of incorporating the intraensemble spread into analysis without making the assumptions of hypothesis testing, such as independence and normality.

\section{Results}

\section{a. Arctic near-surface changes}

The change in ensemble mean ice concentration is the most significant surface change across the Arctic from the late twentieth to late twenty-first century. Much of the central Arctic Ocean loses most or all of its ice in JJA and SON, while these losses shift to the lower-latitude peripheral seas in DJF and MAM (Figs. 1a-d). Large increases in lower-atmospheric air temperature are projected nearly everywhere, but are generally larger where ice losses are greatest (Figs. 1e-h), though this does not always follow across the central Arctic. The greatest temperature increases occur in SON and DJF by a wide margin, with an increase of over $15^{\circ} \mathrm{C}$ over the central Arctic Ocean and over $20^{\circ} \mathrm{C}$ primarily in the Chukchi and Beaufort Seas. 

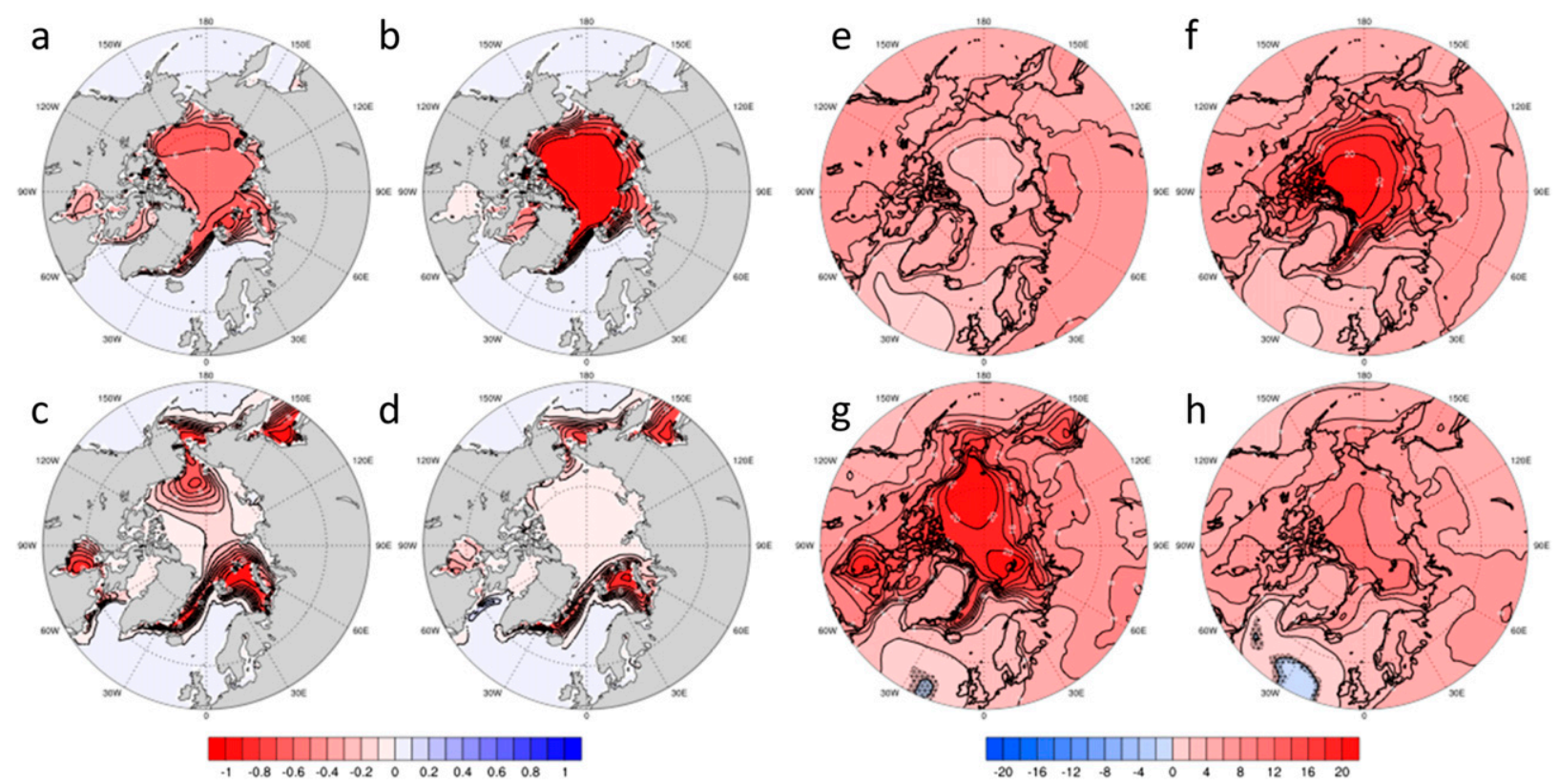

FIG. 1. Projected seasonal 1971-2000 to 2071-2100 change in the CESM-LE mean sea ice fraction for (a) JJA, (b) SON, (c) DJF, and (d) MAM; and air temperature $\left({ }^{\circ} \mathrm{C}\right.$ ) at the lowest model level for (e) JJA, (f) SON, (g) DJF, and (h) MAM. Stippling indicates grid cells where the magnitude of change does not exceed the intraensemble standard deviation.

Decreases in low-level atmospheric stability (Fig. 2) are primarily a function of temperature increases at the surface that destabilize the lower atmosphere. Static stability is calculated as follows:

$$
s=-\left(\frac{T}{\theta}\right)\left(\frac{\partial \theta}{\partial p}\right),
$$

where $s$ is the static stability between the lowermost model levels, while $T$ is the temperature and $\theta$ is the potential temperature at these model levels.

As with other variables, stability changes are most pronounced in SON and DJF when stability significantly decreases across much of the Arctic Ocean but exhibits little change equatorward or over land. The greatest decreases in stability correspond to regions of the greatest increase in surface air temperature (Figs. 1f,g) and decrease in ice concentration (Fig. 1b). During summer, however, there is a slight increase in stability across the entire Arctic Ocean.

Likewise, changes in turbulent heat flux (latent and sensible fluxes, positive change indicating increased upward flux; Fig. 3) serve as an intermediary between sea ice loss and decreased atmospheric stability, primarily by warming the lower atmosphere. Patterns of increased turbulent fluxes most closely follow those of sea ice and temperature particularly in DJF. With a local increase of over $100 \mathrm{Wm}^{-2}$ coming from the surface where sea ice loss is greatest, this represents a significant addition of energy to the lower atmosphere. These turbulent flux increases in DJF clearly occur as a result of the change in ice concentration and are concurrent with the resulting increase in surface temperature. Less significant increases in turbulent fluxes in the spring and even decreases in the summer (Fig. 3) likely occur because the surface temperature tends to remain around the melting point even in the future, whereas the overlying air can more easily rise above this temperature.

\section{b. Arctic near-surface wind speed changes}

The strongest simulated winds over the high latitudes during the recent past occur climatologically over the North Pacific and North Atlantic in all seasons, but particularly in DJF when they exceed a mean of $10 \mathrm{~m} \mathrm{~s}^{-1}$ (Figs. 4a-d). The weakest winds occur over the central Arctic Ocean in every season and are most prevalent where sea ice exists. The CESM-LE historical run compares favorably with climatological $1000-\mathrm{hPa}$ wind speed from the NCEP-NCAR reanalysis (Kalnay et al. 1996; Figs. 4e-h).

The mean wind speed is projected to increase in all seasons by the end of the twenty-first century (Fig. 5), particularly where sea ice loss is greatest-over the central Arctic Ocean in autumn and the peripheral seas in winter (Figs. 1b,c). Using the intraensemble standard deviation of wind speed change to gauge internal variability, nearly all increases over the Arctic Ocean are 

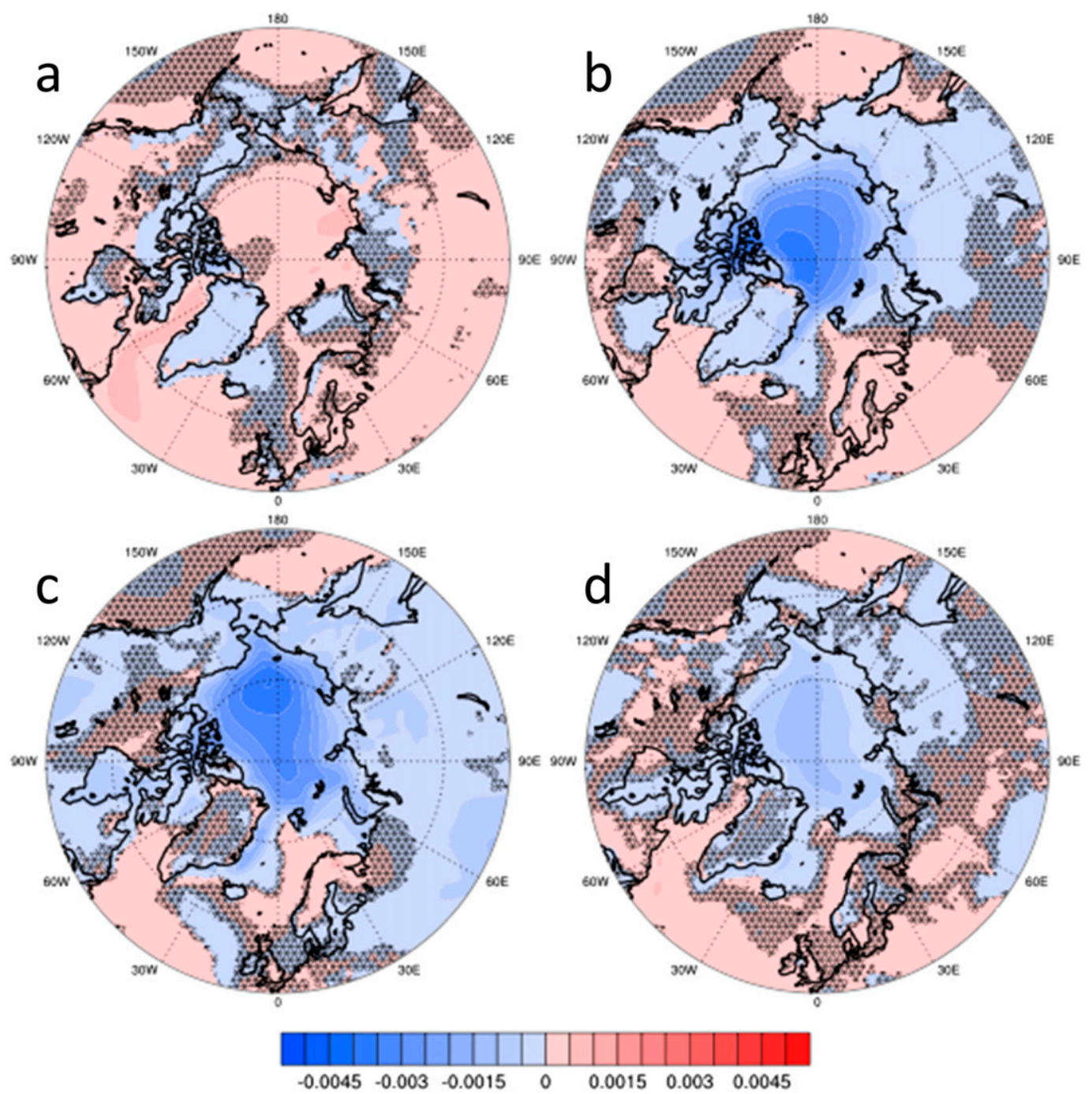

FIG. 2. As in Fig. 1, but for static stability between the two lowermost model levels $\left(\mathrm{K} \mathrm{Pa}^{-1}\right)$.

significant with the exception of MAM (Fig. 5). These projected increases exceed $2 \mathrm{~m} \mathrm{~s}^{-1}$ (Fig. 5), or $50 \%$, in the central Arctic Ocean in SON and the peripheral seas in DJF, closely matching the areas of sea ice loss (Figs. 1a-d) and also those of maximum increases in temperature (Fig. 1e-h). Otherwise, wind increases relatively uniformly across the central Arctic Ocean in SON. The primary areas of increase in DJF are centered over the Beaufort and Chukchi Seas into the Bering Strait, as well as the Barents-Kara Sea, Sea of Okhotsk, Greenland Sea-Denmark Strait, and Hudson Bay. Increases are weaker in MAM but occur in most of the same regions as in DJF. Finally, widespread but weak increases in wind speed of under $1 \mathrm{~m} \mathrm{~s}^{-1}$ occur in JJA across the central Arctic Ocean, with decreases equatorward of similar magnitude. Overall, projected increases in wind speed are several times greater than those observed in the trend of the historical run of the CESM-LE, particularly in autumn and winter (1920-2005; Fig. S1 in the online supplemental material vs Fig. 5). These increases in the historical run are not significant (not shown), especially in SON and DJF, but they are widespread, particularly in maritime regions in JJA and DJF, where the linear trend in $10-\mathrm{m}$ wind speed exceeds $0.5 \mathrm{~m} \mathrm{~s}^{-1}$ over the 86 -yr period.

Because of the apparent inverse relationship in the fall and winter season between changes in ice concentration and wind speed, we next test the nature of this relationship more closely with scatterplots using all ensemble members rather than the ensemble mean (Fig. 6). Surface wind speed increases linearly with decreasing ice concentration in all seasons except summer, 

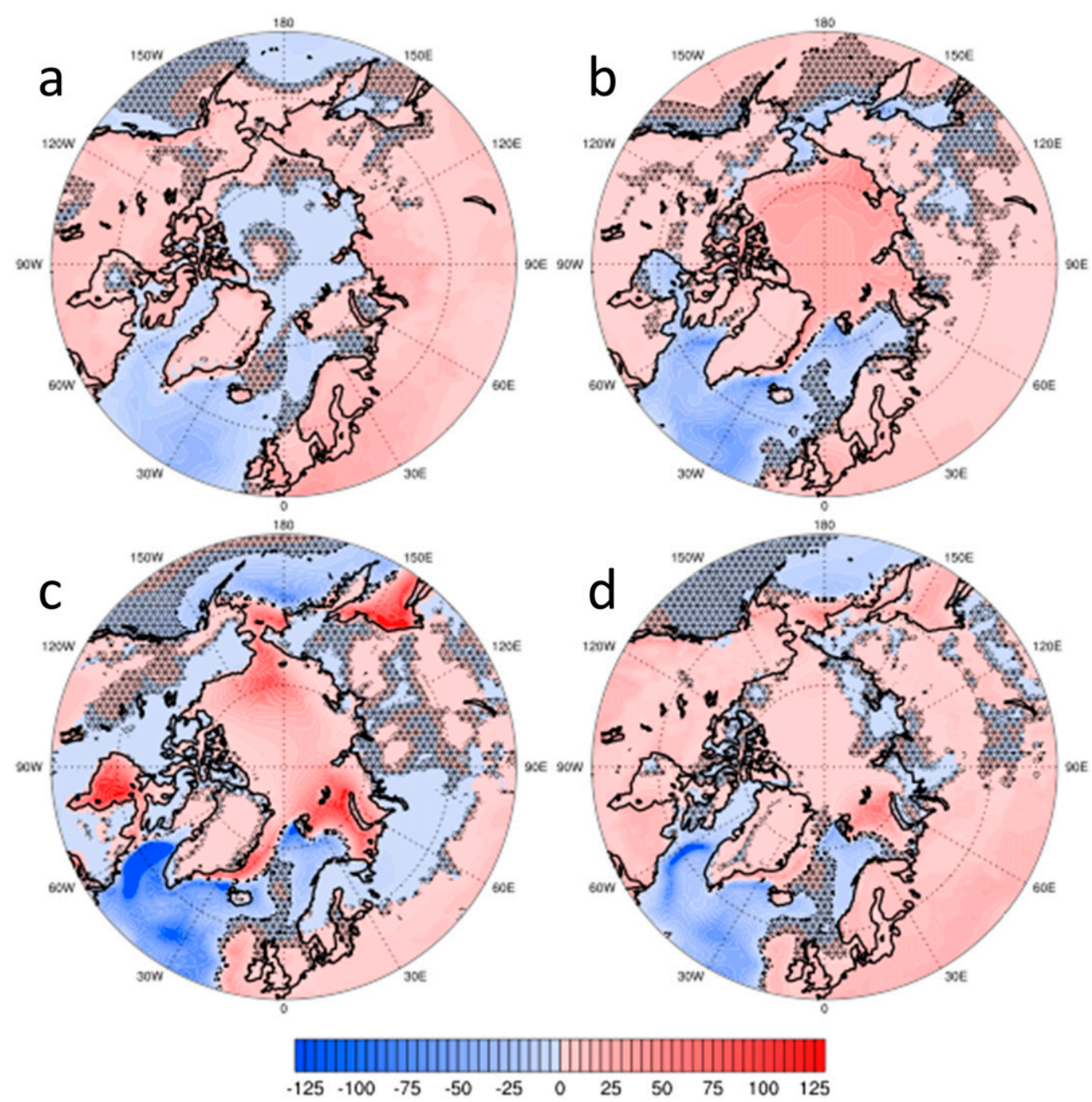

FIG. 3. As in Fig. 1, but for turbulent heat flux $\left(\mathrm{W} \mathrm{m}^{-2}\right)$. Positive change indicates increased upward flux.

with very high Pearson correlation coefficients of $r=$ 0.97 and $r=0.86$ in SON and DJF, respectively (Figs. 6b,c). These correlation coefficients are especially impressive when considering that all grid cells over water, even those with no change in ice cover, are included. The slope of the relationship varies by season, with the greatest slope in DJF and smallest in JJA, when changes in turbulent heat fluxes are small and atmospheric stability generally increases (Figs. 2 and 3).

A very likely reason why winds tend to strengthen where sea ice diminishes is that the surface roughness of sea ice is usually higher than that of open water (Wadhams 2000). Surface roughness is not outputted in the CESM-LE, but the model's air-surface drag coefficient of ocean grid cells under neutral stability conditions $\left(C_{N}\right)$ is much larger for sea ice than open water (nearly 3 times greater at a typical $5 \mathrm{~m} \mathrm{~s}^{-1}$ wind speed).
Consequently, the formulated 10-m wind speed (Large and Pond 1982; Neale et al. 2012) suggests increases where the ocean transitions from sea ice to open water,

$$
U_{10}=U_{A}\left[1+\frac{\sqrt{C_{N}}}{\kappa} \ln \left(\frac{Z_{A}}{10}-\psi\right)\right]^{-1},
$$

where $U_{10}$ is the interpolated wind speed at $10 \mathrm{~m}$ derived from a given wind speed $U_{A}$ at a height $Z_{A}, C_{N}$ is the airsurface drag coefficient at $10 \mathrm{~m}$ under neutral stability, $\kappa$ is the von Kármán constant, and $\psi$ is the integrated flux profile for momentum that is a function of atmospheric stability.

There is also a relatively tight coupling between changes in wind speed and temperature (Fig. 7a), though this is not likely a causal relationship but one arising 

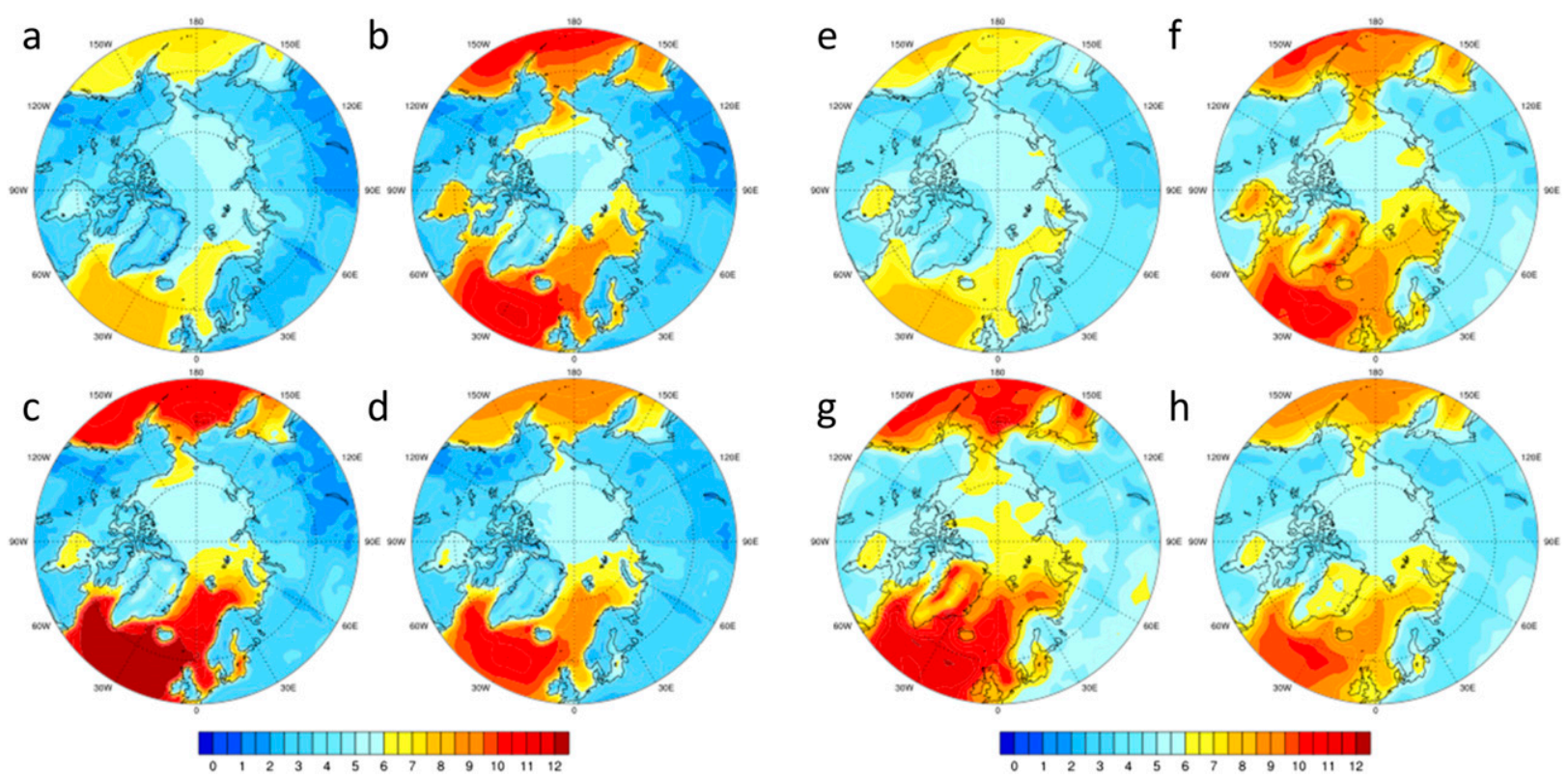

FIG. 4. The 1971-2000 CESM-LE seasonal mean 10-m wind speed for (a) JJA, (b) SON, (c) DJF, and (d) MAM (m s ${ }^{-1}$ ); and 1971-2000 NCEP-NCAR reanalysis seasonal mean 1000-hPa wind speed for (e) JJA, (f) SON, (g) DJF, and (h) MAM.

from both responding to the ice cover (Fig. 6a). This relationship is also approximately linear, with the greatest increases in both occurring in DJF (Fig. 7a, blue) and SON (Fig. 7a, black) and can also be inferred from Fig. 1 and Fig. 5. Interestingly, while there are almost no projected decreases in surface temperature, weak temperature increases correspond to a decrease in wind speed of $1-2 \mathrm{~m} \mathrm{~s}^{-1}$ on average. These points correspond primarily to grid cells in the North Atlantic where wind speeds decrease slightly (Fig. 5c) and stability remains the same or even increases (Fig. 2c). Because there is generally no sea ice to be lost in these regions, there is no decreased surface roughness and no resulting decreased stability to generate increased mean winds.

Sea ice loss also decreases static stability via increased surface warming, which further promotes stronger winds [Eq. (2)]. The relationship between all three of these variables (ice concentration, temperature, wind speed) and static stability appears to be nonlinear. With small changes in air temperature (Fig. 7b), wind speed (Fig. 7c), and ice concentration (Fig. 7d), there is a minimal decrease or even an increase in static stability. This is consistent across all seasons, with the notable exception of DJF static stability in relation to sea ice loss. Therefore, a substantial drop in static stability is associated with the largest loss of sea ice as well as the greatest increase in temperature and wind speed.

The change in wind speed in the lowermost model level demonstrates that the strongest projected increases in wind speed are largely confined to the near surface (Fig. S2). Although the sign of the wind speed changes is nearly the same between the two levels, there is a relatively large difference in magnitude between the lowermost model level and 10-m increases. The patterns of increase are similar, but they are approximately 3 times greater at $10 \mathrm{~m}$ in those areas with a distinct increase in wind, such as the Beaufort and Chukchi Seas.

The mean winds near the surface (Fig. 5) and within the boundary layer (Fig. S2) are clearly projected to increase across much of the Arctic, but whether this is due to a uniform shift in the mean or a disproportionate increase in strong winds is unknown in an analysis of only the mean change. To answer this question, histograms of low-level wind speed change were calculated only for ocean grid cells where the mean wind speed increases (significance was not tested), allowing these projected increases to be parsed into bins to determine the relative contribution of each part of the wind speed distribution. Because the climatological wind speed varies considerably over this domain, separate histograms were calculated for each grid cell and the change in each bin averaged to yield a relative change in each 5-percentile bin size, regardless of the corresponding wind speed.

The histograms demonstrate that much of the large increases in winter and autumn mean winds results from increases in the strongest winds, particularly the 95th percentile, which increases by $30 \%$ in frequency during winter and more than $50 \%$ in autumn (Fig. 8). Because 

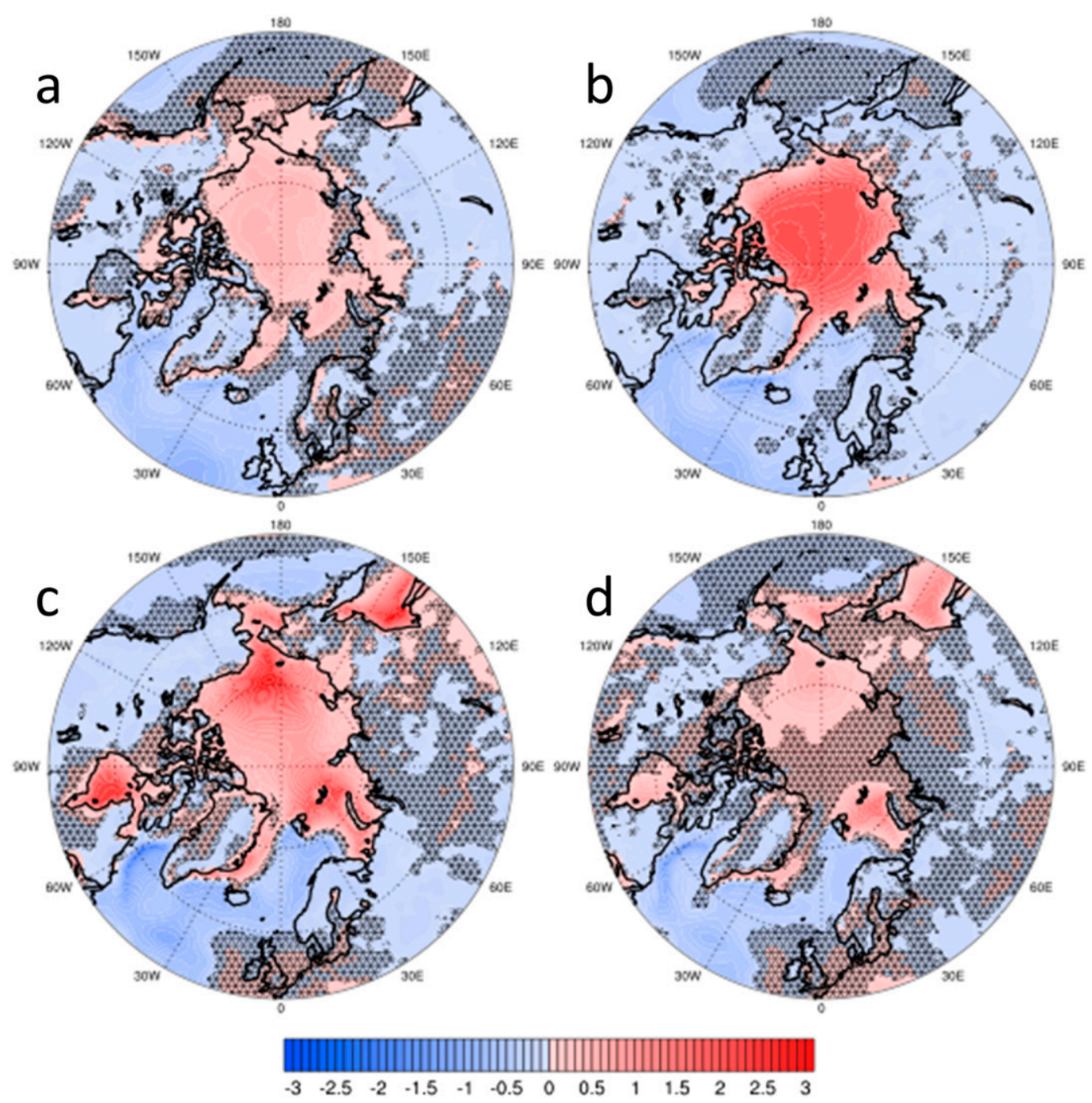

FIG. 5. As in Fig. 1, but for 10-m wind change $\left(\mathrm{m} \mathrm{s}^{-1}\right)$.

the changes over all bins sum to zero, winds of intermediate strength are not necessarily occurring less often but are less frequent relative to bins with a positive change in frequency. This result is consistent with a relatively uniform shift in the distribution to a higher mean, but weighted toward the highest 6-hourly wind speed values. Indeed, the skewness of the distribution increases in all seasons across the Arctic Ocean (Fig. S3), indicating that the amplified strengthening of the most extreme winds is not just an artifact of a rightward shift in the distribution caused by an increase in the mean. To investigate the role of stability in these projected wind speed changes, the 1991-2000 mean low-level atmospheric stability is overlaid over each season's histogram in Fig. 8 to represent the typical twentieth-century stability as a function of wind speed.
Consistent with Eq. (2), we find that the strongest winds coincide with sharply reduced stability. Therefore, the future increase in both mean and extreme wind speeds is explained in part by the overall decline in stability (Fig. 2), which is especially pronounced during autumn and winter when winds strengthen the most.

Because the increases in the 95th percentile of winds are consistently the largest in every season, we plot these increases spatially. The spatial pattern of change is very similar to that of the mean low-level winds (Fig. S2) but of a much greater magnitude (Fig. 9). There is nearly a doubling in frequency of the strongest winds across the Arctic basin in all seasons, greatest in the Beaufort and the Chukchi Seas, though these are not significant in the Barents Sea where stability and sea ice changes are 

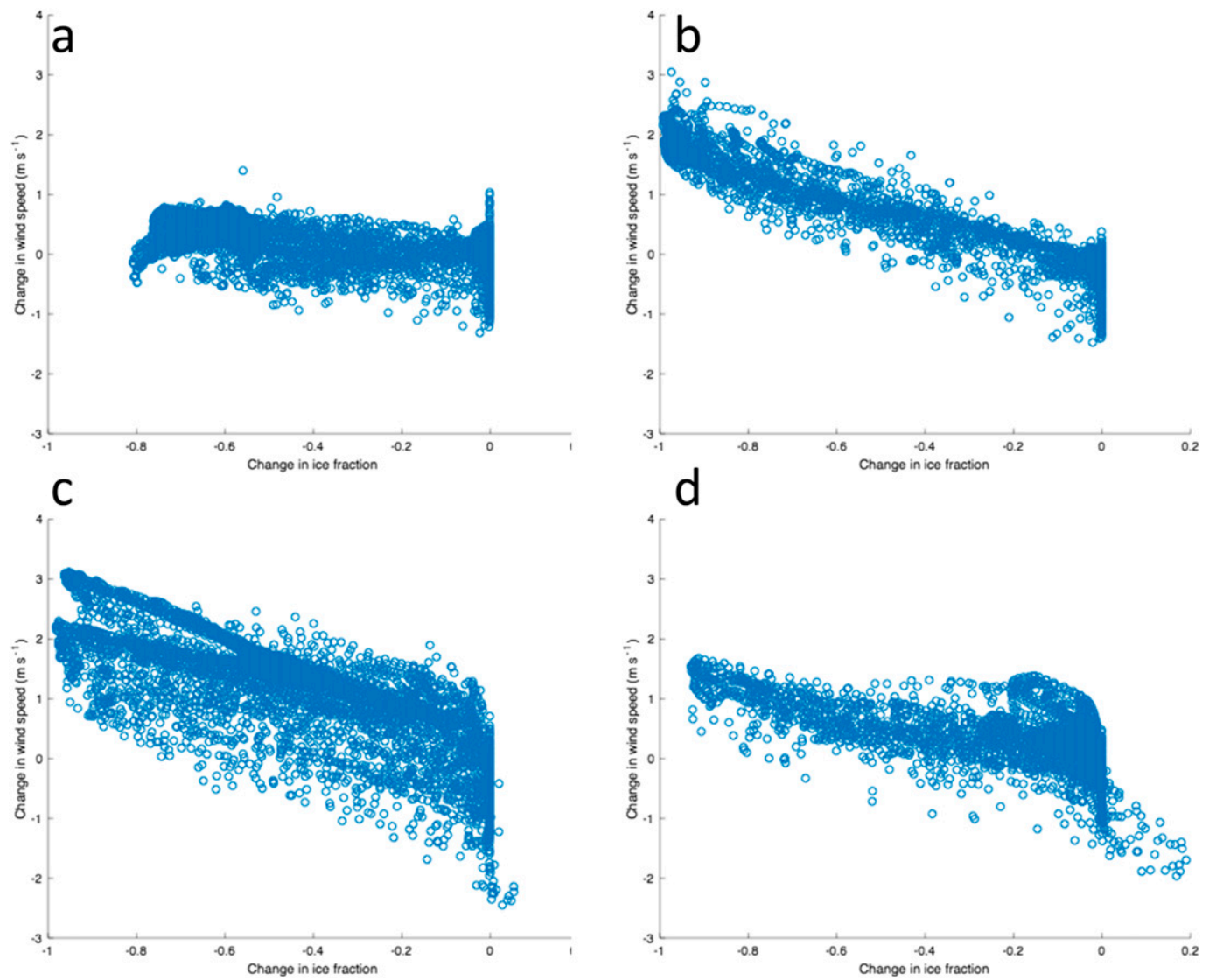

FIG. 6. Scatterplots of changes in 10-m wind vs ice fraction for individual ensemble members for (a) JJA, (b) SON, (c) DJF, and (d) MAM. Only grid cells north of $50^{\circ} \mathrm{N}$ over water are used.

significantly less. This is in slight contrast with the $10-\mathrm{m}$ monthly wind increases (Fig. 5), which show more localized maxima and increases of greatest magnitude in SON and DJF. Together, this is consistent with a disproportionate increase in the right tail of the wind speed distribution at the lowest level, which differs somewhat in its spatial manifestation with winds at $10 \mathrm{~m}$ (Fig. 9 and Fig. S2 vs Fig. 5).

\section{c. Arctic SLP and geostrophic winds}

The CESM-LE ensemble mean projects a lowering of the mean SLP across much of the Arctic, especially in autumn and winter in this century (Fig. 10), consistent with previous modeling results (Jaiser et al. 2012; Screen et al. 2013; Cassano et al. 2014). A notable exception is in the mostly ice-free North Atlantic and GreenlandIceland and Greenland-Iceland-Norwegian (GIN) seas. Otherwise, widespread decreases, up to $4 \mathrm{hPa}$, occur most notably in SON and DJF in the central Arctic and approximately $7 \mathrm{hPa}$ decrease near the Bering Strait in DJF (Fig. 10c). This lowering of SLP is relatively localized and closely collocated with regions of greatest sea ice loss, including Hudson Bay and the Bering Strait region in DJF and basin wide in SON (Fig. 1), as in Gervais et al. (2016). Intraensemble variability in projected SLP is relatively high, as significant drops in SLP are mostly confined to the high Arctic in SON and the Bering, Beaufort, and Chukchi Seas and Sea of Okhotsk in DJF.

The change in geostrophic wind speed, computed offline using the model-outputted monthly SLP fields (Fig. 11), shows where near-surface winds are projected to increase and decrease only because of the change in SLP. Most notably, the large decrease in SLP in the Beaufort and Chukchi Seas in DJF results in a mean geostrophic wind speed increase of more than $1 \mathrm{~m} \mathrm{~s}^{-1}$ in the winter, though the corresponding decrease in Bering Sea implies a northward shift of the Aleutian low. Elsewhere, geostrophic wind changes are mixed and vary by season, and are largely not significant. There is a notable dipole pattern in the Barents-Kara Seas during DJF, similar to that found in the North Pacific. Increases in geostrophic winds also occur across much of Kara Sea, but there are decreases just to the south over Barents 

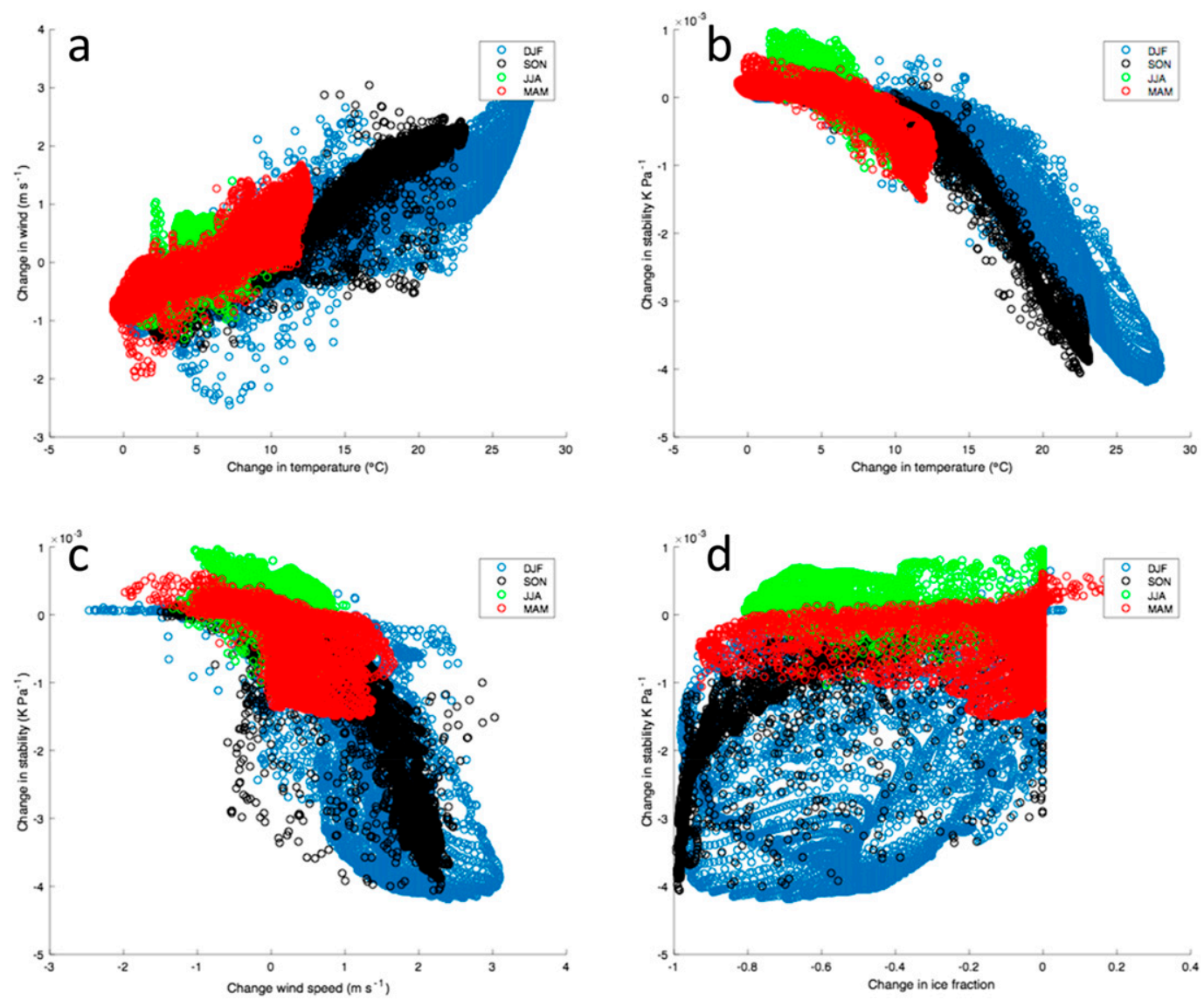

FIG. 7. Scatterplots for all seasons of changes in (a) 10-m wind vs lower-atmospheric temperature, (b) static stability vs lower-atmospheric temperature, (c) 10-m wind vs static stability, and (d) ice fraction vs static stability. Only grid cells north of $50^{\circ} \mathrm{N}$ over water are used. Only $10 \%$ of the grid cells were randomly selected for plotting to reduce visual clutter.

Sea. This also suggests a likely shift in storm track in this region.

\section{d. Wind speed above the surface}

An important question to still resolve is how high these seasonal increases in surface wind extend into the atmosphere. Geopotential heights at $500 \mathrm{hPa}$ in the Arctic are projected to increase in response to the warming and expanding atmospheric column (Semmler et al. 2016; Vavrus et al. 2017). Therefore, changes near the surface may not extend to the free atmosphere or even deep into the boundary layer.

Indeed, the change in mean wind speed near $850 \mathrm{hPa}$ (Fig. 12) exhibits mixed signals with patterns that are mostly dissimilar to the surface and near-surface variables analyzed, indicating that much of the change resulting in stronger near-surface winds is confined to the boundary layer. In particular, the widespread increases in winds at the lowest level over the Arctic Ocean in DJF and SON (Fig. S2) generally reverse sign at the seventh- lowest model level near $850 \mathrm{hPa}$. They are weaker and not significant by our metric at individual grid cells, but the decreases are marginally significant when area averaged north of $70^{\circ} \mathrm{N}$. There is no apparent pattern to the changes of mixed sign above $50^{\circ} \mathrm{N}$, with some broad increases of up to $1 \mathrm{~m} \mathrm{~s}^{-1}$ over parts of the Arctic Ocean in MAM and JJA and decreases of under $1 \mathrm{~m} \mathrm{~s}^{-1}$ in DJF and SON (Fig. S2).

At an intermediate level between $850 \mathrm{hPa}$ and the lowest model level, the change in wind (Fig. S4) more closely follows that at the lowest model level (Fig. S2). While many of the changes above this height are not significant based on the intraensemble spread, the broad coherent patterns in most months suggest that there is some physical mechanism accounting for projected changes above the surface. Further, the area-averaged change in wind speed above $75^{\circ} \mathrm{N}$ near $850 \mathrm{hPa}$ is consistently negative in all seasons and marginally significant (not shown), indicating that there is some coherent tendency for a weakening of winds above the boundary layer over the Arctic Ocean where surface wind increases are robust. 

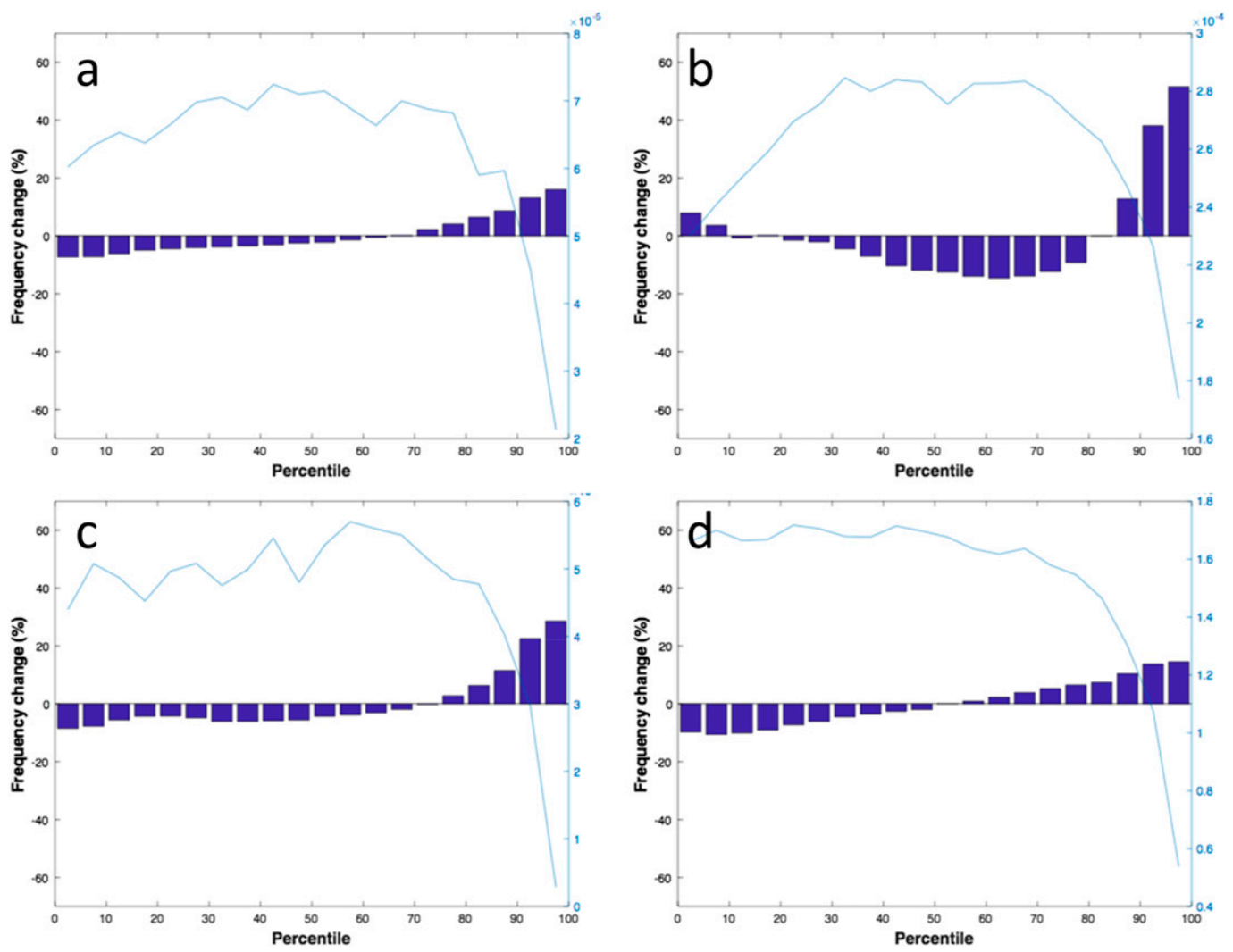

FIG. 8. Projected seasonal 1991-2000 to 2071-80 change in 6-hourly wind speed at the lowest model level for (a) JJA, (b) SON, (c) DJF, and (d) MAM expressed as percentage change in frequency of occurrence of each wind speed bin. Separate histograms were calculated for each grid cell and averaged, and only ocean grid cells where the mean wind speed increases were used. Overlaid is the 1991-2000 mean atmospheric stability corresponding to each wind bin (note the varying right axis).

\section{Discussion and conclusions}

Surface winds are projected to increase in all seasons over the Arctic Ocean, including local strengthening of more than $2 \mathrm{~m} \mathrm{~s}^{-1}$ (up to $50 \%$ ) in SON and DJF. The greatest increases in surface wind occur in the same areas where the strongest warming and the most complete loss of sea ice are found, whereas in the lowest model level the increases occur more uniformly in a broad area across the Arctic Ocean. A large contributor to the increase in the mean wind speed is a greater frequency in the strongest winds, particularly within the 95th percentile (up to a doubling at the lowest level).

Increased surface winds are likely due to a combination of three factors.

Factor 1: Decreased atmospheric stability and increased turbulent mixing of stronger winds from above the surface. This mechanism operates primarily during autumn and winter, when stability reductions are largest, and secondarily during spring. During sum- mer, however, atmospheric stability increases over the Arctic Ocean.

In this case, the stronger surface winds are linked to decreased atmospheric stability, which follows from increased temperature and turbulent fluxes. The robust decreases in stability (Fig. 2) imply increased mixing of stronger winds above the surface. This mechanism was identified as early as Obukhov (1971) and invoked by Seo and Yang (2013) and Desai et al. (2009), the latter of which found that surface warming and increased near-surface wind speeds over Lake Superior have been observed and are consistent with a destabilized boundary layer arising from a weakened vertical temperature gradient. In our study, this appears to be a nonlinear relationship from the Fig. 7 scatterplots as well as the overlaid change in atmospheric stability for each wind speed bin (Fig. 8), suggesting also that the reduction in stability is responsible for the increase in strongest winds. Atmospheric stability increases over the Arctic Ocean during summer because 

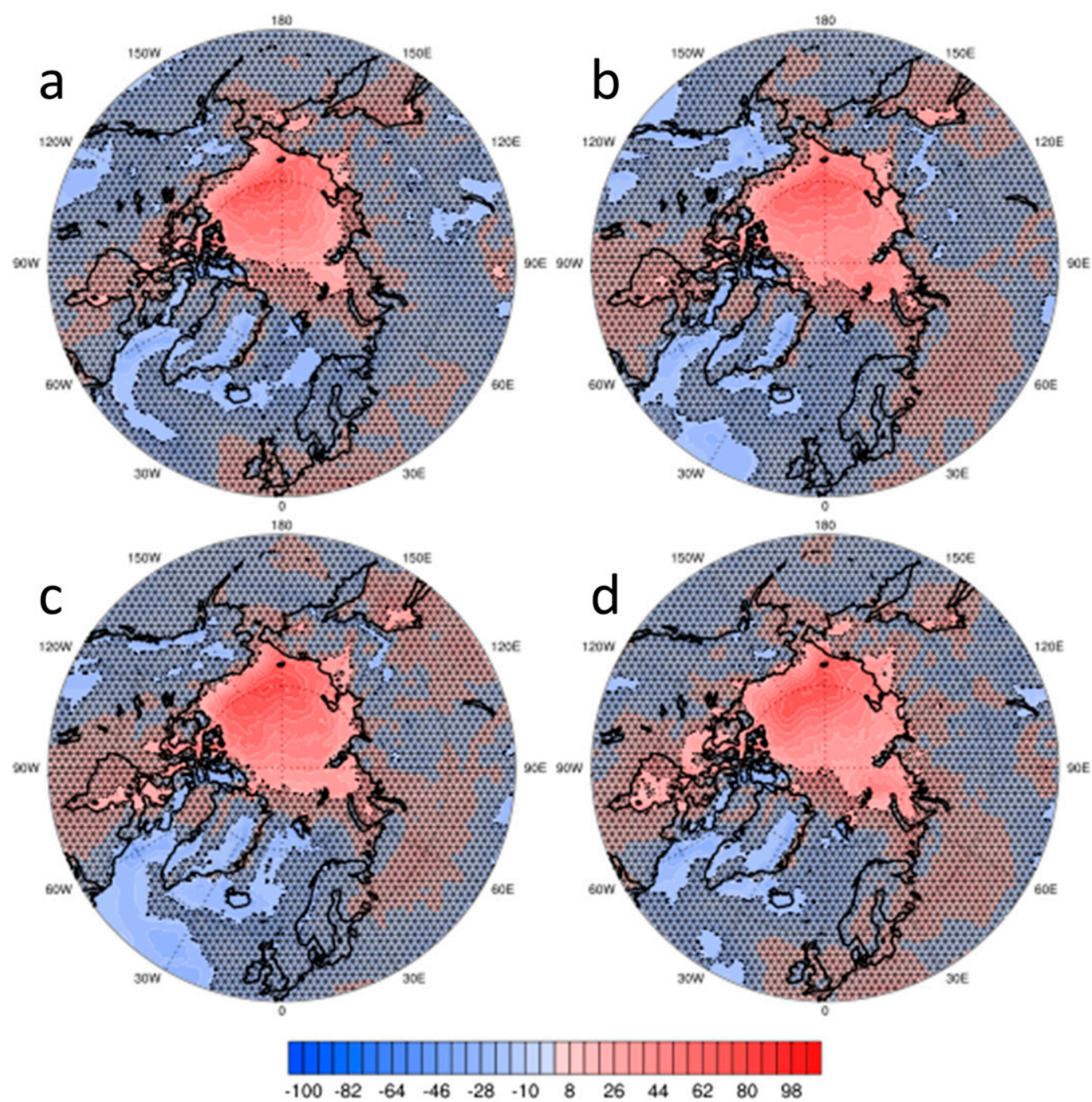

FIG. 9. Projected seasonal 1991-2000 to 2071-80 change (\%) in the CESM-LE wind speed at the lowest level for (a) JJA, (b) SON, (c) DJF, and (d) MAM; percentiles calculated at each grid cell.

the surface is constrained near zero with ice coverage, and in the future the open ocean has a high heat capacity and thus warms slowly compared with air above. This may help explain why the summer relationships among variables appear to be slightly different from other seasons (Fig. 7).

The efficiency of momentum transfer is a strong function of the stability of the layer, so a climatic shift from strong Arctic inversion conditions to a more neutral boundary layer leads to higher wind speeds near the surface. Furthermore, the disproportionate increase in strong winds at the lowest level is associated with the lowest or most-negative values of atmospheric stability. Above the boundary layer, there is evidence of decreased mean wind speeds (Fig. 12) as well as weak increases in upward motion (not shown), and this downward transfer of momentum from the free atmosphere is likely responsible for part of the increased surface wind speeds across the central Arctic, in particular during SON and DJF when atmospheric stability decreases the most (Fig. 2). The weak response of projected winds well above the surface in the troposphere supports a surface-based forcing, consistent with Screen et al. (2013), who noted a lack of ice-driven temperature response above $850 \mathrm{hPa}$ in modeling experiments, and Seo and Yang (2013), who found the Arcticaveraged wind response to sea ice forcing confined to the lower $500 \mathrm{~m}$. Our interpretation also agrees with Knippertz et al. (2000), who attributed strengthened surface winds over Hudson Bay in a greenhouse warming simulation to enhanced turbulent transport 

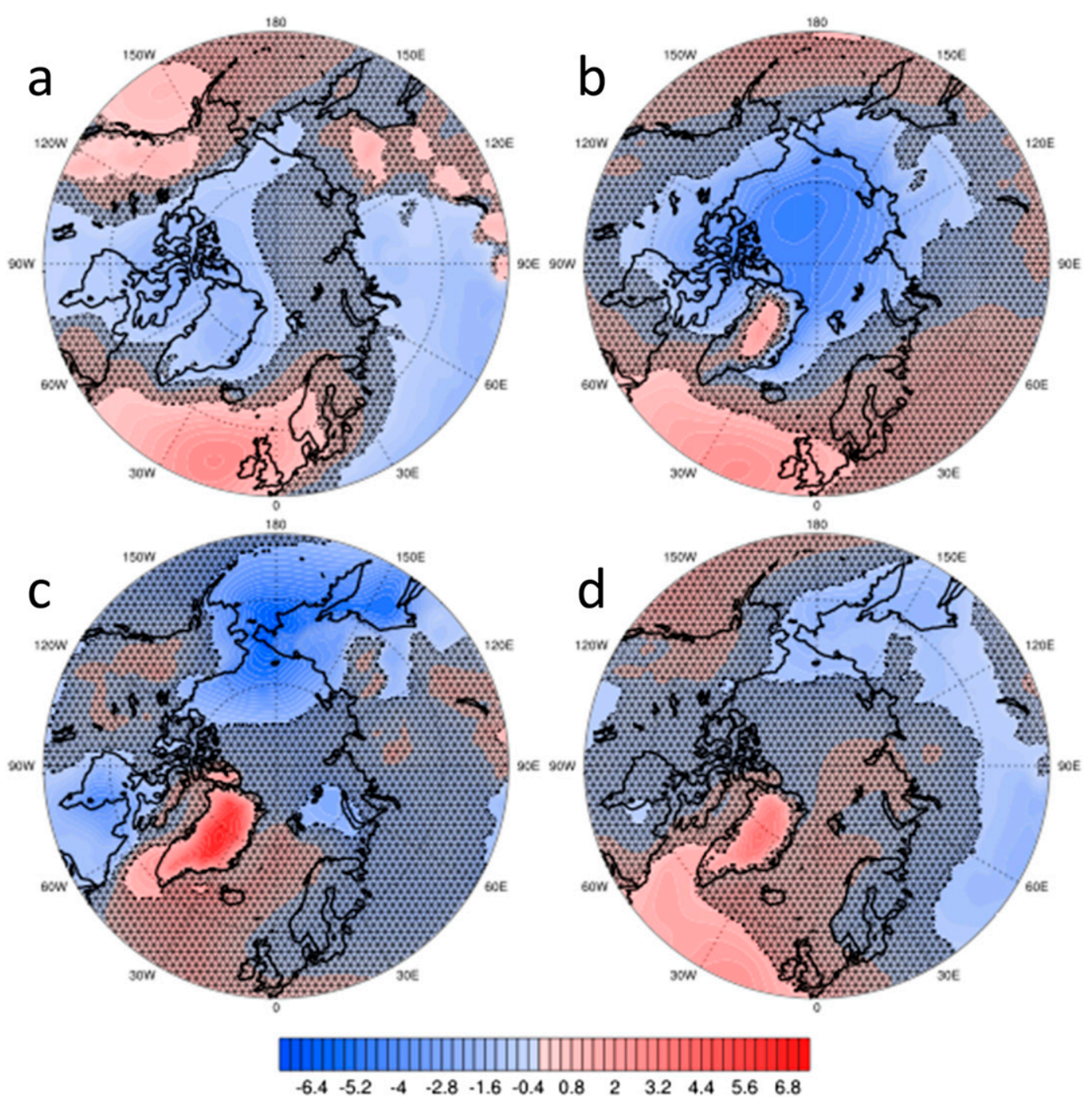

FIG. 10. As in Fig. 1, but for sea level pressure (hPa).

of momentum from the free atmosphere, similar to Seo and Yang (2013).

Factor 2: Increased geostrophic wind speed due primarily to a poleward shift of storm tracks, as well as to a deepened Aleutian low. This mechanism appears to be important regionally during winter.

This factor involves a lowering of SLP as we find in many parts of the Arctic that could represent a general lowering of the background SLP, a change in cyclone frequency and intensity, a shift in the storm tracks or semipermanent dynamic features, or a combination of these. Based on analysis of changes in the geostrophic winds, there is generally not a significant change in the pressure gradient over the Arctic Ocean, but there is evidence that the two major high-latitude storm tracks will shift northward (Yin
2005; Day et al. 2018). The widespread decreases in DJF geostrophic wind speed in the Bering Sea mirrored by increases north of the Bering Strait (Fig. 11) are a good indication that the AL is projected to shift northward and possibly deepen, while a similar pattern occurs in the Barents and Kara Seas, suggesting a shift in the North Atlantic winter storm track as well. However, the strong drop in SLP from the Bering Strait northward suggests that there are other factors at play in addition to a shifting storm track, likely a response to decreased sea ice coverage. Another change to consider is that in the Arctic frontal zone, which would influence future cyclone activity during summer (e.g., Crawford and Serreze 2017; Day and Hodges 2018). However, there are large intermodel differences in its response, and it would therefore be difficult to separate this signal from others using our monthly means. 

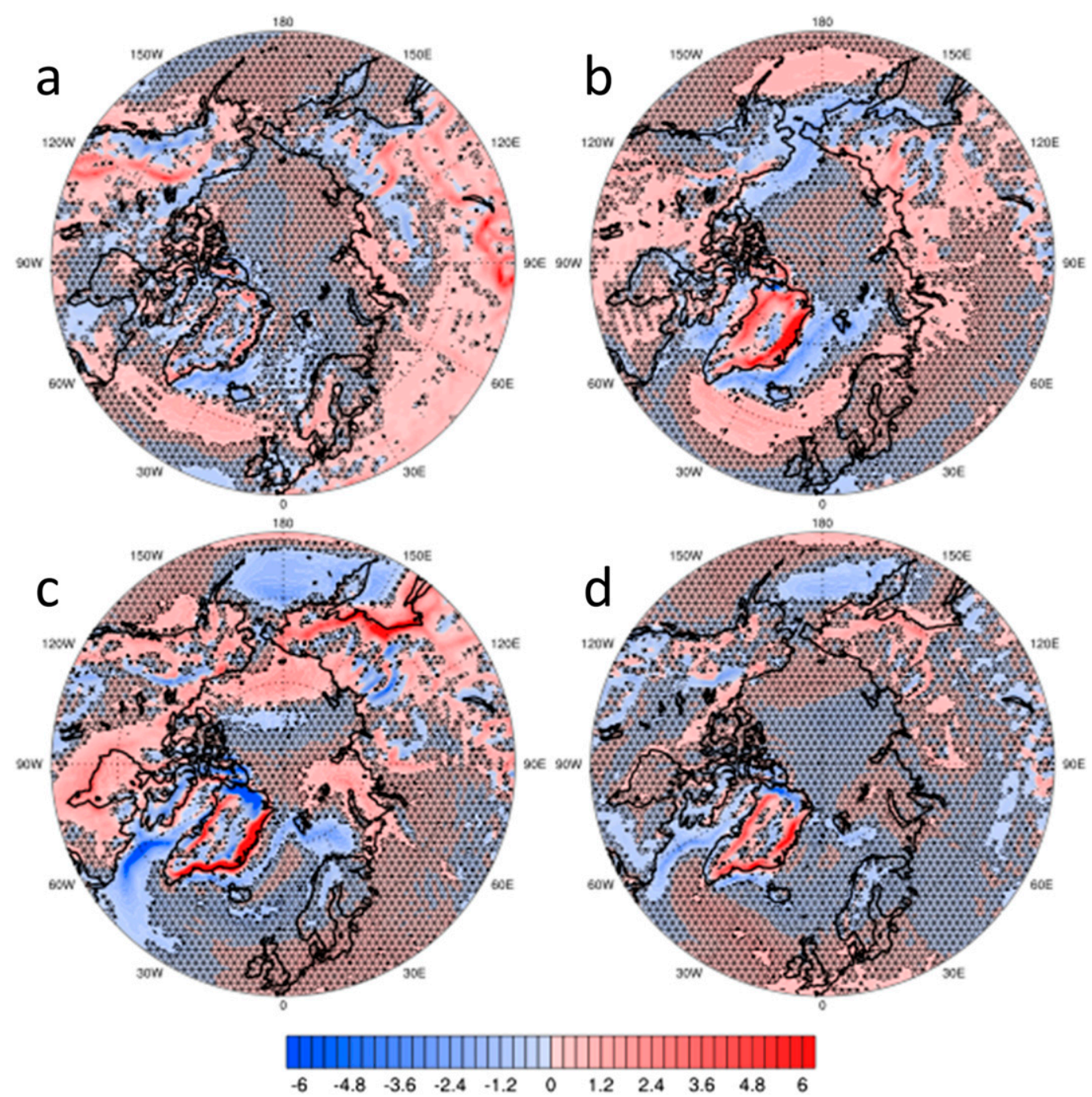

FIG. 11. As in Fig. 1, but for geostrophic wind speed $\left(\mathrm{m} \mathrm{s}^{-1}\right)$.

Widespread increases in geostrophic winds are not apparent across the Arctic, indicating that increased mean surface winds cannot be attributed to a material change in pressure gradient and that lower SLP alone does not generate increased winds. In addition, we find that the areas of greatest drop in SLP correspond to regions with the greatest projected loss of sea ice. This is in agreement with several other studies that have examined the direct effect of a declining ice cover on SLP, generally via a thermodynamically induced lowering of surface pressure particularly in winter (Screen et al. 2014; Cassano et al. 2014; Seo and Yang 2013; Gervais et al. 2016; Gan et al. 2017). We find a drop in mean SLP of up to $7 \mathrm{hPa}$ near the Bering Strait, consistent with a drop of $5.5 \mathrm{hPa}$ in the same area reported by Gan et al. (2017) under RCP8.5 for similar time periods. Locally enhanced surface winds due to thermodynamically induced geostrophic adjustment at the ice margin, as modeled in Seo and Yang (2013), could be a part of these increases, but this mechanism may not be captured accurately at the CESM's spatial resolution. The CESM might also not have the vertical structure to resolve this mechanism, which may largely lie below the 976-hPa hybrid-sigma level. Higher up in the mid- and upper troposphere, we find only a weak pattern or no pattern of coherent change in wind speed (Fig. 12 and Fig. S4). While a warming climate would induce substantial increases in geopotential heights that should materially affect upper-level wind patterns, this may be confounded by internal variations in the circulation. Our analysis is not designed to assess the evolution of low-frequency modes of variability such as that of the Arctic Oscillation, which are likely to be impacted by sea ice loss but via separate pathways. 

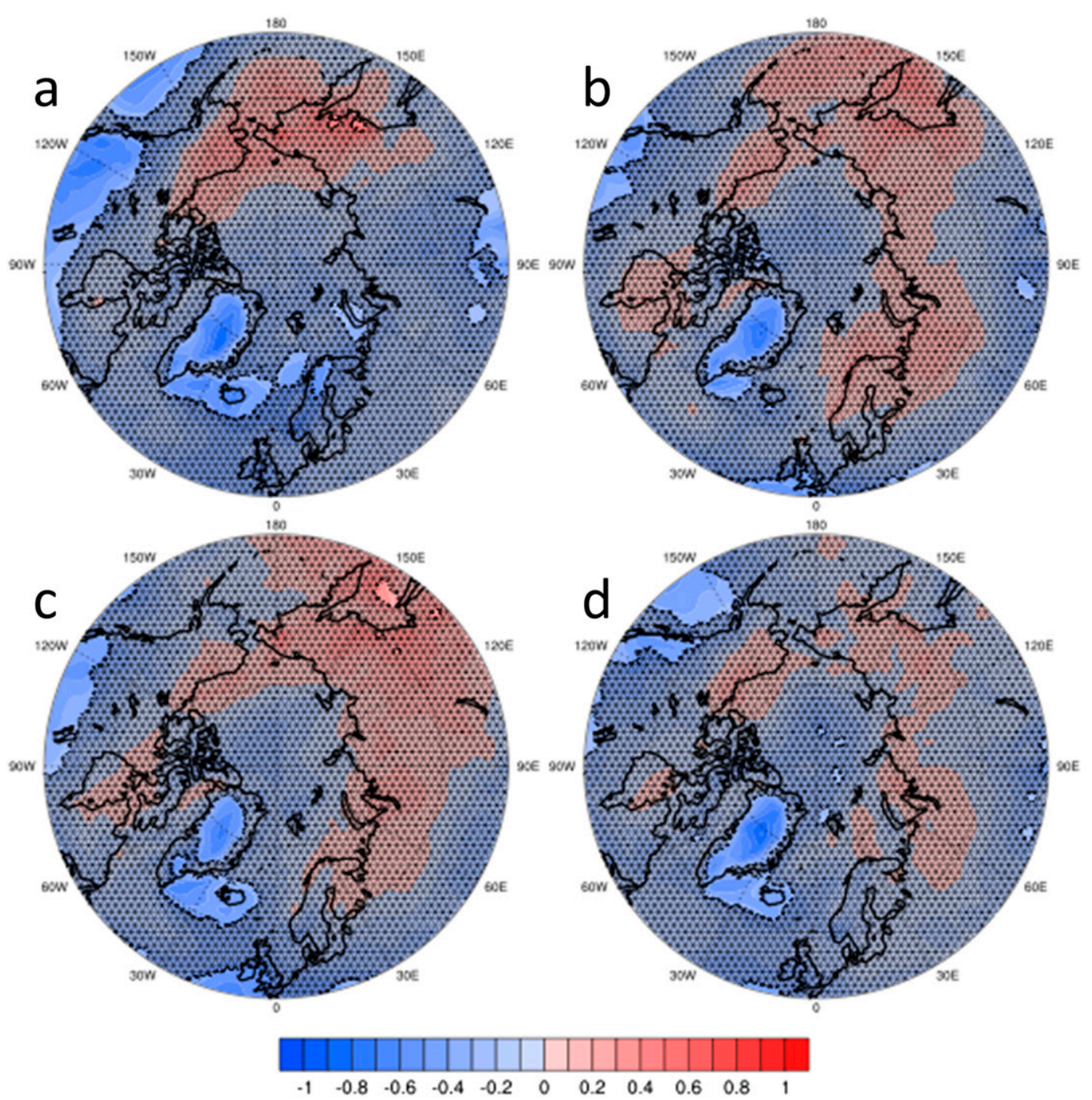

FIG. 12. As in Fig. 9, but for wind near $850 \mathrm{hPa}\left(\mathrm{m} \mathrm{s}^{-1}\right)$.

Factor 3: Decreased surface roughness resulting from the transition of the surface from sea ice to open ocean. This mechanism operates in all seasons and is consistent with the negative correlation between ice concentration and wind speed.

The most widely applicable explanation for the strengthened Arctic Ocean surface winds is the presumed reduction in surface roughness caused by a transition from sea ice to open ocean. This process, factor 3, can account for the stronger winds in every season, the greatest localized wind increases where ice loss maximizes, and the highest inverse correlations between changing sea ice concentration and wind speed throughout the domain during autumn and winter. Although limitations in model output prevent us from precisely quantifying the importance of this mechanism, our interpretation is supported by the much higher surface-atmosphere drag coefficient for sea ice than open water under neutral stability conditions. This feature is present both in the CESM and in observations, but measurements demonstrate a wide range of drag coefficients according to the age and smoothness of ice floes (Overland 1985; Smith 1988; Guest and Davidson 1991; Andreas et al. 1993; Wadhams 2000). A similar conclusion about the importance of surface roughness was reached by Knippertz et al. (2000), who estimated that the smoother surface due to the transition from sea ice to open water in the Greenland Sea could explain about one-third of the overlying surface wind speed increase in a transient greenhouse-forcing simulation.

In summary, our findings of increased Arctic surface winds in the future are consistent with other studies and 
in the investigation of all seasons and underlying physical mechanisms. In particular, the increasing frequency of the strongest winds is corroborated by Dobrynin et al. (2012), who found this to be the case in CMIP5 with up to a $10 \%$ increase in SON wind speeds comparing 2010-2100 to a historical period. Their analysis extended to wave heights, which showed a proportional increase across the ice-free Arctic for the twenty-first century. Stegall and Zhang (2012) found that increases in the 95th percentile in addition to that of the mean wind speeds are already occurring north of Alaska, likely because of the increased open water season in the late summer and fall. Aksenov et al. (2017) projected significant increases in winds and wave heights in DJF across much of the Arctic Ocean with the same local maxima over parts of the Chukchi and Beaufort Seas as we do. Though we do not analyze wave heights, the robust increases in mean wind speed and especially the strongest winds do suggest a commensurate increase in wave heights. In fact, the assumed quadratic dependency of significant wave height on wind speed (Aksenov et al. 2017) implies an especially amplified wave response to the enhanced strengthening of extreme winds, as further supported by recent observational trends (Waseda et al. 2018).

The rapidly warming Arctic generates a multitude of coupled physical and environmental responses. Increased winds and strong wind events contribute to the evolving Arctic environment via increased wave heights, coastal erosion, and further breakup of vulnerable sea ice. In addition, wave heights and freezing spray, for example, are an important consideration in an increasingly navigable Arctic that is becoming more economically attractive to commercial shipping (Melia et al. 2016). The growing problem of Arctic coastal erosion (Overeem et al. 2011) is known to be exacerbated by thawing permafrost, rising sea level, and the loss of a buffering ice pack (Barnhart et al. 2014), and our study suggests that strengthening winds will be yet another factor. Even the smaller simulated wind increases during summer could still be important by coinciding with the emergence of a warmer and mostly ice-free Arctic Ocean in that season. Physically, we provide new evidence to the body of literature of the cascading set of atmospheric responses that is amplified with the transition from ice cover to open ocean. Under the current emissions trajectory, these should become more evident as this transition continues.

Acknowledgments. We wish to acknowledge three anonymous reviewers for their thoughtful input in improving the manuscript. Support was provided by the NOAA Climate Program Office under Climate Variability and Predictability Program Grant NA15OAR4310166. This project is partially funded by the Joint Institute for the Study of the Atmosphere and Ocean (JISAO) under NOAA Cooperative Agreement NA10OAR4320148, contribution number 2017-087, and Pacific Marine Environmental Laboratory contribution number 4671 . We would like to acknowledge high-performance computing support from Yellowstone (ark:/85065/d7wd3xhc) provided by NCAR's Computational and Information Systems Laboratory, sponsored by the National Science Foundation.

\section{REFERENCES}

Aksenov, Y., E. E. Popova, A. Yool, A. J. G. Nurser, T. D. Williams, L. Bertino, and J. Bergh, 2017: On the future navigability of Arctic sea routes: High-resolution projections of the Arctic Ocean and sea ice. Mar. Policy, 75, 300-317, https:// doi.org/10.1016/j.marpol.2015.12.027.

Andreas, E. L., M. A. Lange, S. F. Ackley, and P. Wadhams, 1993: Roughness of Weddell Sea ice and estimates of the air-ice drag coefficient. J. Geophys. Res., 98, 12 439-12 452, https://doi.org/ 10.1029/93JC00654.

Barnhart, K. R., R. S. Anderson, I. Overeem, C. Wobus, G. D. Clow, and F. E. Urban, 2014: Modeling erosion of ice-rich permafrost bluffs along the Alaskan Beaufort Sea coast. J. Geophys. Res. Earth Surf., 119, 1155-1179, https://doi.org/10.1002/2013JF002845.

Bengtsson, L., K. I. Hodges, and E. Roeckner, 2006: Storm tracks and climate change. J. Climate, 19, 3518-3543, https://doi.org/ 10.1175/JCLI3815.1.

Boer, G. J., G. Flato, and D. Ramsden, 2000: A transient climate change simulation with greenhouse gas and aerosol forcing: Projected climate to the twenty-first century. Climate Dyn., 16, 427-450, https://doi.org/10.1007/s003820050338.

Cassano, E. N., J. J. Cassano, M. E. Higgins, and M. C. Serreze, 2014: Atmospheric impacts of an Arctic sea ice minimum as seen in the Community Atmosphere Model. Int. J. Climatol., 34, 766-779, https://doi.org/10.1002/joc.3723.

Cavalieri, D. J., and C. L. Parkinson, 2012: Arctic sea ice variability and trends, 1979-2010. Cryosphere, 6, 881-889, https://doi.org/ 10.5194/tc-6-881-2012.

Comiso, J. C., W. N. Meier, and R. Gersten, 2017: Variability and trends in the Arctic Sea ice cover: Results from different techniques. J. Geophys. Res. Oceans, 122, 6883-6900, https:// doi.org/10.1002/2017JC012768.

Crawford, A., and M. Serreze, 2017: Projected changes in the Arctic frontal zone and summer Arctic cyclone activity in the CESM Large Ensemble. J. Climate, 30, 9847-9869, https:// doi.org/10.1175/JCLI-D-17-0296.1.

Day, J. J., and K. I. Hodges, 2018: Growing land-sea temperature contrast and the intensification of Arctic cyclones. Geophys. Res. Lett., 45, 3673-3681, https://doi.org/10.1029/2018GL077587.

_ M. M. Holland, and K. I. Hodges, 2018: Seasonal differences in the response of Arctic cyclones to climate change in CESM1. Climate Dyn., 50, 3885-3903, https://doi.org/10.1007/s00382-017-3767-x.

Desai, A. R., J. A. Austin, V. Bennington, and G. A. McKinley, 2009: Stronger winds over a large lake in response to weakening air-to-lake temperature gradient. Nat. Geosci., 2, 855858, https://doi.org/10.1038/ngeo693.

Deser, C., R. Tomas, M. Alexander, and D. Lawrence, 2010: The seasonal atmospheric response to projected Arctic sea ice loss in the late twenty-first century. J. Climate, 23, 333-351, https:// doi.org/10.1175/2009JCLI3053.1. 
Dobrynin, M., J. Murawsky, and S. Yang, 2012: Evolution of the global wind wave climate in CMIP5 experiments. Geophys. Res. Lett., 39, L18606, https://doi.org/10.1029/2012GL052843.

Francis, J. A., W. Chan, D. J. Leathers, J. R. Miller, and D. E. Veron, 2009: Winter Northern Hemisphere weather patterns remember summer Arctic sea-ice extent. Geophys. Res. Lett., 36, L07503, https://doi.org/10.1029/2009GL037274.

Francis, O. P., G. G. Panteleev, and D. E. Atkinson, 2011: Ocean wave conditions in the Chukchi Sea from satellite and in situ observations. Geophys. Res. Lett., 38, L24610, https://doi.org/ 10.1029/2011GL049839.

Gan, B., L. Wu, F. Jia, S. Li, W. Cai, H. Nakamura, M. A. Alexander, and A. J. Miller, 2017: On the response of the Aleutian low to greenhouse warming. J. Climate, 30, 39073925, https://doi.org/10.1175/JCLI-D-15-0789.1.

Gervais, M., E. Atallah, J. R. Gyakum, and L. B. Tremblay, 2016: Arctic air masses in a warming world. J. Climate, 29, 23592373, https://doi.org/10.1175/JCLI-D-15-0499.1.

Guest, P. S., and K. L. Davidson, 1991: The aerodynamic roughness of different types of sea ice. J. Geophys. Res., 96, 4709-4721, https://doi.org/10.1029/90JC02261.

Hughes, M., and J. J. Cassano, 2015: The climatological distribution of extreme Arctic winds and implications for ocean and sea ice processes. J. Geophys. Res. Atmos., 120, 7358-7377, https:// doi.org/10.1002/2015JD023189.

Hurrell, J. W., and Coauthors, 2013: The Community Earth System Model: A framework for collaborative research. Bull. Amer. Meteor. Soc., 94, 1339-1360, https://doi.org/10.1175/ BAMS-D-12-00121.1.

Jahn, A., J. E. Kay, M. M. Holland, and D. M. Hall, 2016: How predictable is the timing of a summer ice-free Arctic? Geophys. Res. Lett., 43, 9113-9120, https://doi.org/10.1002/2016GL070067.

Jaiser, R., K. Dethloff, D. Handorf, A. Rinke, and J. Cohen, 2012: Impact of sea ice cover changes on the Northern Hemisphere atmospheric winter circulation. Tellus, 64A, 11595, https://doi.org/ 10.3402/tellusa.v64i0.11595.

Kalnay, E., and Coauthors, 1996: The NCEP/NCAR 40-Year Reanalysis Project. Bull. Amer. Meteor. Soc., 77, 437-470, https:// doi.org/10.1175/1520-0477(1996)077<0437:TNYRP>2.0.CO;2.

Kay, J. E., and Coauthors, 2015: The Community Earth System Model (CESM) large ensemble project: A community resource for studying climate change in the presence of internal climate variability. Bull. Amer. Meteor. Soc., 96, 1333-1349, https://doi.org/10.1175/BAMS-D-13-00255.1.

Khon, V. C., I. I. Mokhov, F. A. Pogarskiy, A. Babanin, K. Dethloff, A. Rinke, and H. Matthes, 2014: Wave heights in the 21st century Arctic Ocean simulated with a regional climate model. Geophys. Res. Lett., 41, 2956-2961, https://doi.org/ 10.1002/2014GL059847.

Knippertz, P., U. Ulbrich, and P. Speth, 2000: Changing cyclones and surface wind speeds over the North Atlantic and Europe in a transient GHG experiment. Climate Res., 15, 109-122, https://doi.org/10.3354/cr015109.

Knutti, R., D. Masson, and A. Gettelman, 2013: Climate model genealogy: Generation CMIP5 and how we got there. Geophys. Res. Lett., 40, 1194-1199, https://doi.org/10.1002/grl.50256.

Koyama, T., J. Stroeve, J. Cassano, and A. Crawford, 2017: Sea ice loss and Arctic cyclone activity from 1979 to 2014. J. Climate, 30, 4735-4754, https://doi.org/10.1175/JCLI-D-16-0542.1.

Kwok, R., and D. A. Rothrock, 2009: Decline in Arctic sea ice thickness from submarine and ICESat records: 1958-2008. Geophys. Res. Lett., 36, L15501, https://doi.org/10.1029/ 2009GL039035.
- G. F. Cunningham, M. Wensnahan, I. Rigor, H. J. Zwally, and D. Yi, 2009: Thinning and volume loss of the Arctic Ocean sea ice cover: 2003-2008. J. Geophys. Res., 114, C07005, https://doi.org/10.1029/2009JC005312.

Labe, Z., G. Magnusdottir, and H. Stern, 2018: Variability of Arctic sea ice thickness using PIOMAS and the CESM Large Ensemble. J. Climate, 31, 3233-3247, https://doi.org/10.1175/ JCLI-D-17-0436.1.

Large, W. G., and S. Pond, 1982: Sensible and latent heat flux measurements over the ocean. J. Phys. Oceanogr., 12, 464-482, https:// doi.org/10.1175/1520-0485(1982)012<0464:SALHFM > 2.0.CO;2.

Lindsay, R., and A. Schweiger, 2015: Arctic sea ice thickness loss determined using subsurface, aircraft, and satellite observations. Cryosphere, 9, 269-283, https://doi.org/10.5194/tc-9-269-2015.

Maslanik, J. A., C. Fowler, J. Stroeve, S. Drobot, J. Zwally, D. Yi, and W. Emery, 2007: A younger, thinner Arctic ice cover: Increased potential for rapid, extensive sea-ice loss. Geophys. Res. Lett., 34, L24501, https://doi.org/10.1029/2007GL032043.

- J. Stroeve, C. Fowler, and W. Emery, 2011: Distribution and trends in Arctic sea ice age through spring 2011. Geophys. Res. Lett., 38, L13502, https://doi.org/10.1029/2011GL047735.

Massonnet, F., T. Fichefet, H. Goosse, C. M. Bitz, G. PhilipponBerthier, M. M. Holland, and P.-Y. Barriat, 2012: Constraining projections of summer Arctic sea ice. Cryosphere, 6, 1383-1394, https://doi.org/10.5194/tc-6-1383-2012.

McCusker, K. E., P. J. Kushner, J. C. Fyfe, M. Sigmond, V. V. Kharin, and C. M. Bitz, 2017: Remarkable separability of circulation response to Arctic sea ice loss and greenhouse gas forcing. Geophys. Res. Lett., 44, 7955-7964, https://doi.org/ 10.1002/2017GL074327.

McDonald, R. E., 2011: Understanding the impact of climate change on Northern Hemisphere extra-tropical cyclones. Climate Dyn., 37, 1399-1425, https://doi.org/10.1007/s00382-010-0916-x.

McInnes, K. L., T. A. Erwin, and J. M. Bathols, 2011: Global Climate Model projected changes in $10 \mathrm{~m}$ wind speed and direction due to anthropogenic climate change. Atmos. Sci. Lett., 12, 325-333, https://doi.org/10.1002/asl.341.

Melia, N., K. Haines, and E. Hawkins, 2016: Sea ice decline and 21 st century trans-Arctic shipping routes. Geophys. Res. Lett., 43, 9720-9728, https://doi.org/10.1002/2016GL069315.

Murray, R. J., and I. Simmonds, 1995: Responses of climate and cyclones to reductions in Arctic winter sea ice. J. Geophys. Res., 100, 4791-4806, https://doi.org/10.1029/94JC02206.

Neale, R. B., and Coauthors, 2012: Description of the NCAR Community Atmosphere Model (CAM 5.0). NCAR Tech. Note, NCAR/TN-486+STR, 274 pp., www.cesm.ucar.edu/ models/cesm1.0/cam/docs/description/cam5_desc.pdf.

Nghiem, S. V., I. G. Rigor, D. K. Perovich, P. Clemente-Colón, J. W. Weatherly, and G. Neumann, 2007: Rapid reduction of Arctic perennial sea ice. Geophys. Res. Lett., 34, L19504, https://doi.org/10.1029/2007GL031138.

Notz, D., and J. Marotzke, 2012: Observations reveal external driver for Arctic sea-ice retreat. Geophys. Res. Lett., 39, L08502, https://doi.org/10.1029/2012GL051094.

Obukhov, A. M., 1971: Turbulence in an atmosphere with a nonuniform temperature. Bound.-Layer Meteor., 2, 7-29, https:// doi.org/10.1007/BF00718085.

Onarheim, I. H., T. Eldevik, L. H. Smedsrud, and J. C. Stroeve, 2018: Seasonal and regional manifestation of Arctic sea ice loss. J. Climate, 31, 4917-4932, https://doi.org/10.1175/ JCLI-D-17-0427.1.

Overeem, I., R. S. Anderson, C. W. Wobus, G. D. Clow, F. E. Urban, and N. Matell, 2011: Sea ice loss enhances wave action at the 
Arctic coast. Geophys. Res. Lett., 38, L17503, https://doi.org/ 10.1029/2011GL048681.

Overland, J. E., 1985: Atmospheric boundary layer structure and drag coefficients over sea ice. J. Geophys. Res., 90, 9029-9049, https://doi.org/10.1029/JC090iC05p09029.

— , and M. Wang, 2010: Large-scale atmospheric circulation changes are associated with the recent loss of Arctic sea ice. Tellus, 62A, 1-9, https://doi.org/10.1111/j.1600-0870.2009.00421.x.

Peings, Y., J. Cattiaux, S. Vavrus, and G. Magnusdottir, 2017: Late twenty-first-century changes in the midlatitude atmospheric circulation in the CESM large ensemble. J. Climate, 30, 59435960, https://doi.org/10.1175/JCLI-D-16-0340.1.

Rinke, A., W. Maslowski, K. Dethloff, and J. Clement, 2006: Influence of sea ice on the atmosphere: A study with an Arctic atmospheric regional climate model. J. Geophys. Res., 111, D16103, https://doi.org/10.1029/2005JD006957.

Rosenblum, E., and I. Eisenman, 2017: Sea ice trends in climate models only accurate in runs with biased global warming. J. Climate, 30, 6265-6278, https://doi.org/10.1175/JCLI-D-16-0455.1.

Royer, J. F., S. Planton, and M. Déqué, 1990: A sensitivity experiment for the removal of Arctic sea ice with the French spectral general circulation model. Climate Dyn., 5, 1-17, https://doi.org/ 10.1007/BF00195850.

Salathé, E. P., Jr., 2006: Influences of a shift in North Pacific storm tracks on western North American precipitation under global warming. Geophys. Res. Lett., 33, L19820, https://doi.org/ 10.1029/2006GL026882.

Screen, J. A., and I. Simmonds, 2010: The central role of diminishing sea ice in recent Arctic temperature amplification. Nature, 464, 1334-1337, https://doi.org/10.1038/ nature09051.

_ _ _ C. Deser, and R. Tomas, 2013a: The atmospheric response to three decades of observed arctic sea ice loss. J. Climate, 26, 1230-1248, https://doi.org/10.1175/JCLI-D-12-00063.1.

—_, C. Deser, I. Simmonds, and R. Tomas, 2014: Atmospheric impacts of Arctic sea-ice loss, 1979-2009: Separating forced change from atmospheric internal variability. Climate Dyn., 43, 333-344, https://doi.org/10.1007/ s00382-013-1830-9.

Semmler, T., L. Stulic, T. Jung, N. Tilinina, C. Campos, S. Gulev, and D. Koracin, 2016: Seasonal atmospheric responses to reduced Arctic sea ice in an ensemble of coupled model simulations. J. Climate, 29, 5893-5913, https://doi.org/10.1175/ JCLI-D-15-0586.1.

Seo, H., and J. Yang, 2013: Dynamical response of the Arctic atmospheric boundary layer process to uncertainties in sea-ice concentration. J. Geophys. Res. Atmos., 118, 12 383-12 402, https://doi.org/10.1002/2013JD020312.

Sepp, M., and J. Jaagus, 2011: Changes in the activity and tracks of Arctic cyclones. Climatic Change, 105, 577-595, https://doi.org/ 10.1007/s10584-010-9893-7.

Serreze, M. C., and J. Stroeve, 2015: Arctic sea ice trends, variability and implications for seasonal ice forecasting. Philos. Trans. Roy. Soc. London, 373A, 20140159, https://doi.org/10.1098/rsta.2014.0159.

— M. M. Holland, and J. Stroeve, 2007: Perspectives on the Arctic's shrinking sea-ice cover. Science, 315, 1533-1536, https://doi.org/10.1126/science.1139426.

— , A. P. Barrett, J. Stroeve, D. N. Kindig, and M. M. Holland, 2009: The emergence of surface-based Arctic amplification. Cryosphere, 3, 11-19, https://doi.org/10.5194/tc-3-11-2009.

Sinclair, M. R., and I. G. Watterson, 1999: Objective assessment of extratropical weather systems in simulated climates. J. Climate,
12, 3467-3485, https://doi.org/10.1175/1520-0442(1999)012<3467: OAOEWS $>2.0 . \mathrm{CO} ; 2$.

Smith, S. D., 1988: Coefficients for sea surface wind stress, heat flux, and wind profiles as a function of wind speed and temperature. J. Geophys. Res., 93, 15 467-15 472, https://doi.org/10.1029/ JC093iC12p15467.

Sorteberg, A., and J. E. Walsh, 2008: Seasonal cyclone variability at $70^{\circ} \mathrm{N}$ and its impact on moisture transport into the Arctic. Tellus, 60A, 570-586, https://doi.org/10.1111/ j.1600-0870.2008.00314.x.

Spreen, G., R. Kwok, and D. Menemenlis, 2011: Trends in Arctic sea ice drift and role of wind forcing: 1992-2009. Geophys. Res. Lett., 38, L19501, https://doi.org/10.1029/2011GL048970.

Stegall, S. T., and J. Zhang, 2012: Wind field climatology, changes, and extremes in the Chukchi-Beaufort Seas and Alaska North Slope during 1979-2009. J. Climate, 25, 8075-8089, https://doi.org/10.1175/JCLI-D-11-00532.1.

Stopa, J. E., F. Ardhuin, and F. Girard-Ardhuin, 2016: Wave climate in the Arctic 1992-2014: Seasonality and trends. Cryosphere, 10, 1605-1629, https://doi.org/10.5194/tc-10-1605-2016.

Stroeve, J., and D. Notz, 2015: Insights on past and future seaice evolution from combining observations and models. Global Planet. Change, 135, 119-132, https://doi.org/ 10.1016/j.gloplacha.2015.10.011.

, V. Kattsov, A. Barrett, M. Serreze, T. Pavlova, M. Holland, and W. N. Meier, 2012a: Trends in Arctic sea ice extent from CMIP5, CMIP3 and observations. Geophys. Res. Lett., 39, L16502, https://doi.org/10.1029/2012GL052676.

— M. C. Serreze, M. M. Holland, J. E. Kay, J. Malanik, and A. P. Barrett, 2012b: The Arctic's rapidly shrinking sea ice cover: A research synthesis. Climatic Change, 110, 1005-1027, https:// doi.org/10.1007/s10584-011-0101-1.

Swart, N. C., J. C. Fyfe, E. Hawkins, J. E. Kay, and A. Jahn, 2015: Influence of internal variability on Arctic sea-ice trends. Nat. Climate Change, 5, 86-89, https://doi.org/10.1038/ nclimate2483.

Trigo, I. F., 2006: Climatology and interannual variability of stormtracks in the Euro-Atlantic sector: A comparison between ERA-40 and NCEP/NCAR reanalyses. Climate Dyn., 26, 127-143, https://doi.org/10.1007/s00382-005-0065-9.

Vavrus, S. J., F. Wang, J. E. Martin, J. A. Francis, Y. Peings, and J. Cattiaux, 2017: Changes in North American atmospheric circulation and extreme weather: Influence of Arctic amplification and Northern Hemisphere snow cover. J. Climate, 30, 4317-4333, https://doi.org/10.1175/JCLI-D-16-0762.1.

Vihma, T., 2014: Effects of Arctic sea ice decline on weather and climate: A review. Surv. Geophys., 35, 1175-1214, https:// doi.org/10.1007/s10712-014-9284-0.

Wadhams, P., 2000: Ice in the Ocean. Gordon and Breach Science Publishers, $351 \mathrm{pp}$.

Wang, M., and J. E. Overland, 2012: A sea ice free summer Arctic within 30 years: An update from CMIP5 models. Geophys. Res. Lett., 39, L18501, https://doi.org/10.1029/2012GL052868.

Wang, X. L., Y. Feng, V. R. Swail, and A. Cox, 2015: Historical changes in the Beaufort-Chukchi-Bering Seas surface winds and waves, 1971-2013. J. Climate, 28, 7457-7469, https://doi.org/ 10.1175/JCLI-D-15-0190.1.

Warshaw, M., and R. R. Rapp, 1973: An experiment on the sensitivity of a global circulation model. J. Appl. Meteor., 12, 43-49, https://doi.org/10.1175/1520-0450(1973)012<0043: AEOTSO $>2.0 . \mathrm{CO} ; 2$.

Waseda, T., A. Webb, K. Sato, J. Inoue, A. Kohout, B. Penrose, and S. Penrose, 2018: Correlated increase of high ocean waves 
and winds in the ice-free waters of the Arctic Ocean. Sci. Rep. 8, 4489, https://doi.org/10.1038/s41598-018-22500-9.

Watterson, I. G., 2006: The intensity of precipitation during extratropical cyclones in global warming simulations: A link to cyclone intensity? Tellus, 58A, 82-97, https://doi.org/10.1111/ j.1600-0870.2006.00147.x.

Yin, J. H., 2005: A consistent poleward shift of the storm tracks in simulations of 21st century climate. Geophys. Res. Lett., 32, L18701, https://doi.org/10.1029/2005GL023684.

Young, I. R., J. Vinoth, S. Zieger, and A. V. Babanin, 2012: Investigation of trends in extreme value wave height and wind speed. J. Geophys. Res., 117, C00J06, https://doi.org/10.1029/2011JC007753.
Zhang, J., S. T. Stegall, and X. Zhang, 2018: Wind-sea surface temperature-sea ice relationship in the Chukchi-Beaufort Seas during autumn. Environ. Res. Lett., 13, 034008, https:// doi.org/10.1088/1748-9326/aa9adb.

Zhang, X., J. E. Walsh, J. Zhang, U. S. Bhatt, and M. Ikeda, 2004: Climatology and interannual variability of Arctic cyclone activity: 1948-2002. J. Climate, 17, 2300-2317, https://doi.org/ 10.1175/1520-0442(2004)017<2300:CAIVOA >2.0.CO;2.

Zolina, O., and S. K. Gulev, 2002: Improving the accuracy of mapping cyclone numbers and frequencies. Mon. Wea. Rev., 130, 748-759, https://doi.org/10.1175/1520-0493(2002)130<0748: ITAOMC $>2.0 . \mathrm{CO} ; 2$. 